\title{
Above- and below-ground net primary productivity across ten Amazonian forests on contrasting soils
}

\author{
L. E. O. C. Aragão ${ }^{1,2}$, Y. Malhi ${ }^{1}$, D. B. Metcalfe ${ }^{1,2}$, J. E. Silva-Espejo ${ }^{3}$, E. Jiménez ${ }^{4}$, D. Navarrete Ne, $^{4,5}$, Almeida ${ }^{6}$, \\ A. C. L. Costa $^{7}$, N. Salinas ${ }^{1,3}$, O. L. Phillips ${ }^{9}$, L. O. Anderson ${ }^{1}$, E. Alvarez ${ }^{4}$, T. R. Baker ${ }^{9}$, P. H. Goncalvez ${ }^{7,8}$, \\ J. Huamán-Ovalle ${ }^{3}$, M. Mamani-Solórzano ${ }^{3}$, P. Meir ${ }^{12}$, A. Monteagudo ${ }^{13}$, S. Patiño ${ }^{4}$, M. C. Peñuela ${ }^{4}$, A. Prieto ${ }^{14}$, \\ C. A. Quesada ${ }^{9,10,11}$, A. Rozas-Dávila ${ }^{3}$, A. Rudas ${ }^{15}$, J. A. Silva Jr. ${ }^{7}$, and R. Vásquez ${ }^{13}$ \\ ${ }^{1}$ Environmental Change Institute, School of Geography and the Environment, University of Oxford, South Parks Road, \\ OX1 3QY, Oxford, UK \\ ${ }^{2}$ Climate Change and Sustainability Group, School of Geography, University of Exeter, Amory Building, Rennes Drive, \\ Exeter, Devon, EX4 4RJ, UK \\ ${ }^{3}$ Universiadad Nacional San Antonio Abad, Cusco, Peru \\ ${ }^{4}$ Grupo de Estudio de Ecosistemas Terrestres Tropicales, Universidad Nacional de Colombia, Leticia, Colombia \\ ${ }^{5}$ Fundación Puerto Rastrojo, Bogotá, Colombia \\ ${ }^{6}$ Museu Paraense Emilio Goeldi, 66077-530 Belem, Brazil \\ ${ }^{7}$ Universidade Federal do Para, Belem, Para, Brazil \\ ${ }^{8}$ Universidade Federal de Vicosa, Vicosa, Minas Gerais, Brazil \\ ${ }^{9}$ Earth and Biosphere Institute, School of Geography, University of Leeds, LS2 9JT, UK \\ ${ }^{10}$ Institito National de Pesquisas Amazônicas, Manaus, Brazil \\ ${ }^{11}$ Departamento de Ecologia, Universidade de Brasília, Brazil \\ ${ }^{12}$ School of Geography, University of Edinburgh, Edinburgh, UK \\ ${ }^{13}$ Jardin Botanico de Missouri, Oxapampa, Pasco, Peru \\ ${ }^{14}$ Instituto Alexander von Humboldt, Claustro de San Agustín, Villa de Lleva, Boyaca, Colombia \\ ${ }^{15}$ Universidad Nacional de Colombia, Instituto de Ciencias Naturales, Apartado 7495, Bogota, Colombia
}

Received: 18 December 2008 - Published in Biogeosciences Discuss.: 25 February 2009

Revised: 11 November 2009 - Accepted: 11 November 2009 - Published: 1 December 2009

\begin{abstract}
The net primary productivity (NPP) of tropical forests is one of the most important and least quantified components of the global carbon cycle. Most relevant studies have focused particularly on the quantification of the above-ground coarse wood productivity, and little is known about the carbon fluxes involved in other elements of the NPP, the partitioning of total NPP between its above- and below-ground components and the main environmental drivers of these patterns. In this study we quantify the above- and below-ground NPP of ten Amazonian forests to address two questions: (1) How do Amazonian forests allocate productivity among its above- and below-ground components? (2) How do soil and leaf nutrient status and soil texture affect the productivity of Amazonian forests? Using a standardized methodology to mea-
\end{abstract}

sure the major elements of productivity, we show that NPP varies between $9.3 \pm 1.3 \mathrm{MgC} \mathrm{ha}^{-1} \mathrm{yr}^{-1}$ (mean \pm standard error), at a white sand plot, and $17.0 \pm 1.4 \mathrm{MgCha}^{-1} \mathrm{yr}^{-1}$ at a very fertile Terra Preta site, with an overall average of $12.8 \pm 0.9 \mathrm{MgC} \mathrm{ha}^{-1} \mathrm{yr}^{-1}$. The studied forests allocate on average $64 \pm 3 \%$ and $36 \pm 3 \%$ of the total NPP to the aboveand below-ground components, respectively. The ratio of above-ground and below-ground NPP is almost invariant with total NPP. Litterfall and fine root production both increase with total NPP, while stem production shows no overall trend. Total NPP tends to increase with soil phosphorus and leaf nitrogen status. However, allocation of NPP to below-ground shows no relationship to soil fertility, but appears to decrease with the increase of soil clay content.

\section{Correspondence to: L. E. O. C. Aragão}

(leocaragao@gmail.com)

Published by Copernicus Publications on behalf of the European Geosciences Union. 


\section{Introduction}

Plants are able to capture and accumulate atmospheric carbon via photosynthesis or gross primary productivity (GPP), and synthesis of organic compounds. The amount of organic carbon retained in plant biomass over time, which results from the difference between GPP and autotrophic respiration $\left(R_{a}\right)$, is known as net primary productivity (NPP). Globally, it has been estimated that the terrestrial biosphere fixes annually between $46 \mathrm{Pg} \mathrm{C}$ (Del Grosso et al., 2008) and $63 \mathrm{Pg} \mathrm{C}$ (Grace, 2004) through NPP, approximately the same amount that is fixed by oceans (Field et al., 1998). Despite covering only around $13 \%$ of the total land cover area (Bartholomé and Belward, 2005; Del Grosso et al., 2008), tropical forests alone have a major impact on global carbon cycling, accounting for about a third of overall terrestrial NPP (Field et al., 1998; Malhi and Grace, 2000; Grace, 2004; Del Grosso et al., 2008).

Detailed understanding of the total NPP of tropical forests, including both above- and below-ground productivity ( $\mathrm{NPP}_{\mathrm{AG}}$ and $\mathrm{NPP}_{\mathrm{BG}}$, respectively), is limited by challenging logistics and elevated research costs. Hitherto, most of the on-site measurements of NPP for tropical forests have been based on few sites and do not present adequate data on below-ground NPP (Clark et al., 2001a). Amazonia, home to over half of the world's tropical forest area, is no exception. Most studies that attempted to measure NPP in this ecosystem focused exclusively on above-ground wood productivity (e.g. Chambers et al., 2001; Malhi et al., 2004; Quesada et al., 2009a). Malhi et al. (2009) compiled a synthesis of carbon production for three Amazonian forests (key sites of the Large Scale Biosphere-Atmosphere Experiment in Amazonia - LBA) based on detailed measurements of the individual above and below-ground $\mathrm{C}$ cycling components. GPP estimate from the component studies was in agreement with estimates derived from ecosystem flux measurements, giving increased confidence in both approaches to estimating tropical forest's GPP. Moreover, this study indicated that oldgrowth or infertile tropical forests may have low carbon use

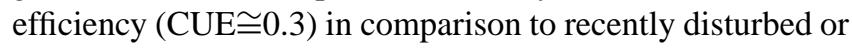

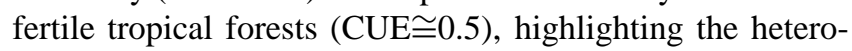
geneity of forest processes in the Amazon.

In order to improve our understanding of the biogeochemical function of Amazonian forests, and model simulations of their vulnerability to climate change and human-induced impacts, there is a need to expand our knowledge on the primary productivity of these ecosystems, taking into account their spatial heterogeneity. The understanding of how these processes vary across the region and across soil types would therefore assist in planning the development of the Amazon region within the global climate change mitigation and adaptation framework.

Based on the analysis of 104 forest plots across Amazonia from the RAINFOR network (Amazon Forest Inventory Network; Malhi et al., 2002), Malhi et al. (2004) demon- strated that wood production varies by up to a factor of three across Amazonian forests. The lowest wood productivities are found on heavily weathered oxisols (United States Department of Agriculture soil classification - USDA), or ferralsols (World Reference Base soil classification - WRB) in lowland eastern Amazonia; the highest on fertile alluvial soils and inceptsols (USDA classification system) or fluvisols and cambisols (WRB classification system) in western Amazonia (Ecuador and Peru). More fertile sites in western Amazonia tend to favour fast growing, low wood density species (Baker et al., 2004), which are likely to allocate relatively more to wood and leaf production and less to structural and chemical defences and their associated construction and maintenance metabolic costs. A companion paper in this issue (Chave et al., 2009) examines patterns of canopy NPP across Amazonia in greater detail. This study suggests that soil type is not a major determinat of litterfall patterns across Amazonia, however, infertile white sand soils $\left(5.42 \pm 1.91 \mathrm{Mg} \mathrm{ha}^{-1} \mathrm{yr}^{-1}\right)$ have significantly lower litterfall production than other soil types and seems to prioritize carbon allocation to photosynthetic organs over that to reproduction.

Another (Quesada et al., 2009a) relates Amazon aboveground productivity to its potential edaphic and climate drivers. This analysis revealed that forest structure and dynamics are strongly related to physical and chemical edaphic conditions. On one hand tree turnover rates were mostly influenced by soil physical properties, on the other hand, forest growth rates were mainly related to available soil phosphorus, suggesting that soils may be a determinant factor on forest functioning and composition at a Basin wide scale. However, beyond the stand-level wood and leaf production pattern across the region, almost nothing is known about the amount of carbon being allocated by other components of the NPP, the partitioning of total NPP (NPP total $)$ between its above- and below-ground components, $\mathrm{NPP}_{\mathrm{AG}}$ and $\mathrm{NPP}_{\mathrm{BG}}$ respectively, and the main environmental drivers of any site-to-site variation. Therefore, in this paper we provide the first inter-site quantification of the major components of $\mathrm{NPP}_{\text {total }}$ for Amazonian forest stands on contrasting soils using standardized on-site measurements of the major aboveand below-ground components of forest NPP.

The total NPP of a tropical forest stand can be broken down as:

$\mathrm{NPP}_{\text {total }}=\mathrm{NPP}_{\mathrm{AG}}+\mathrm{NPP}_{\mathrm{BG}}$

Each of the components of $\mathrm{NPP}_{\text {total }}$ can be described as the sum of its subcomponents (Clark et al., 2001a; Malhi et al., 2009). Thus, $\mathrm{NPP}_{\mathrm{AG}}$ can be expressed as:

$\mathrm{NPP}_{\mathrm{AG}}=\mathrm{NPP}_{\text {canopy }}+\mathrm{NPP}_{\text {branch }}+\mathrm{NPP}_{\text {stem }}+\mathrm{NPP}_{\mathrm{VOC}}$

where $\mathrm{NPP}_{\text {canopy }}$ is the canopy production (leaves, twigs $<2 \mathrm{~cm}$ diameter, flowers and fruits), $\mathrm{NPP}_{\text {branch }}$ is the production of branches $>2 \mathrm{~cm}$ diameter, $\mathrm{NPP}_{\text {stem }}$ is the production of coarse woody biomass, calculated as the change in 
the stem biomass of trees $>10 \mathrm{~cm}$ diameter plus the biomass recruited during the measurement interval. $\mathrm{NPP}_{\mathrm{VOC}}$ is the emission of volatile organic carbon compounds (see Malhi et al., 2009, for greater discussion of these terms). The canopy production, $\mathrm{NPP}_{\text {canopy }}$ is estimated to be equal to the rate of litterfall; this assumes the forest is in near-steady state and that there is little loss of this production through insect herbivory or decomposition before the litter hits the ground.

$\mathrm{NPP}_{\mathrm{BG}}$ can be divided into three major subcomponents (Eq. 3):

$\mathrm{NPP}_{\mathrm{BG}}=\mathrm{NPP}_{\text {fineroot }}+\mathrm{NPP}_{\text {coarseroot }}+\mathrm{NPP}_{\text {exudates }}$

Where $\mathrm{NPP}_{\text {fineroot }}$ is the fine root $(<2 \mathrm{~mm}$ diameter $)$ production, $\mathrm{NPP}_{\text {coarseroot }}$ is the production of coarse roots ( $>2 \mathrm{~mm}$ diameter) and $\mathrm{NPP}_{\text {exudates }}$ is the carbon loss through exudates and mycorrhizae, which is challenging to measure and is not considered here.

In this study we quantify the above- and below-ground NPP of ten Amazonian forests to address two general questions: (1) how do Amazonian forests allocate productivity among its above- and below-ground components? (2) How do soil and leaf nutrient status and soil texture affect the productivity of Amazonian forests?

Based on the concepts above, these two questions can be decomposed into five specific questions, which we tackle in this paper:

1. How do $\mathrm{NPP}_{\mathrm{AG}}$ and $\mathrm{NPP}_{\mathrm{BG}}$ and their subcomponents vary with $\mathrm{NPP}_{\text {total }}$ ?

2. Is the partitioning between $\mathrm{NPP}_{\mathrm{AG}}$ and $\mathrm{NPP}_{\mathrm{BG}}$ invariant with changes in $\mathrm{NPP}_{\text {total }}$ ?

3. Is the partitioning between $\mathrm{NPP}_{\text {stem }}$ and $\mathrm{NPP}_{\text {canopy }}$ constant?

4. How does NPP vary with soil and leaf nutrients status?

5. How does the partitioning of NPP vary with soil and leaf properties?

We therefore aim to investigate in this study how $\mathrm{NPP}_{\text {total }}$ and its subcomponents vary across a wide range of Amazonian forests on different soil types. Specifically, our objectives are to:

1. Quantify and describe the patterns of $\mathrm{NPP}_{\text {total }}$ across a gradient of soil conditions.

2. Quantify the partitioning of $\mathrm{NPP}_{\text {total }}$ among its major above and below-ground components.

3. Investigate if the partitioning between $\mathrm{NPP}_{\text {canopy }}$ and $\mathrm{NPP}_{\text {stem }}$ is constant.

4. Determine how soil fertility and texture, based on available soil phosphorus, nitrogen and clay content data (Quesada et al., 2009a, b) influence NPP in Amazonian forests.

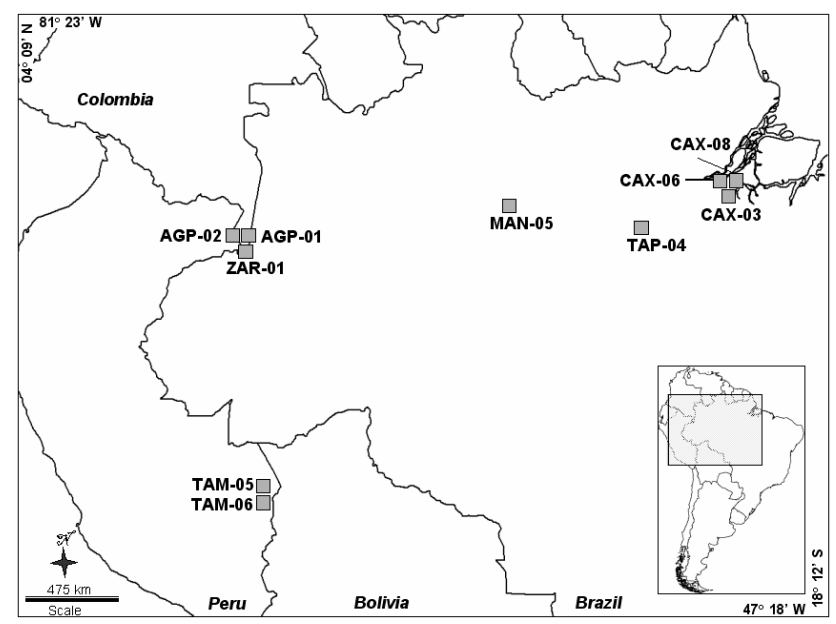

Fig. 1. Location of the study area within South America (lowerright panel) and location of the studied plots within the studied area. Plot locations are approximated in order to display all plots.

\section{Study sites}

We analysed the NPP total and its above- and below-ground subcomponents for ten forest plots across Amazonia (Fig. 1). We directly quantified NPP employing a consistent methodology in eight plots: three plots at Caxiuanã, Brazil (CAX03, CAX-06 and CAX-08), two at Tambopata, Peru (TAM05 and TAM-06), two at Amacayacu, Colombia (AGP-01 and AGP-02) and one at Zafire, Colombia (ZAR-01). In addition, we used published data compiled from two other Brazilian sites in Manaus (MAN-05) and Tapajós (TAP-04) (Malhi et al., 2009) to support our analysis.

These sites are part of the intensive surveyed plots within the RAINFOR network where measurements of all the major components of the $\mathrm{C}$ cycle are being measured since the end of 2004 or beginning of 2005 (see methods section), and where stem productivity has been measured since as early as the 1980s. All directly studied plots were one-hectare (ha) in area; the results from Manaus and Tapajós were a synthesis from several study plots (Malhi et al., 2009). A summary of plots name, location and basic climate data (Malhi et al., 2004) is given in Table 1.

All forests surveyed in this study are "primary" old-growth rainforests with the exception of CAX-08, which is a well preserved late successional forest growing on a very fertile Indian Dark Earth (or Terra Preta do Indio) soil (Hortic Archeo-Anthrosol, Kampf et al., 2003). This soil was formed by human activities from ancient inhabitants that have occupied this area between 720-300 years BP (Ruivo and Cunha, 2003; Lehmann et al., 2003). This was selected as one of the few Terra Preta sites in the region covered by forest that has remained largely undisturbed for at least 40 years since the creation of Caxiuanã National Forest reserve. More details about each site surveyed are given below. For each site 
Table 1. Site codes, locations and climatic characteristics of the ten Amazonian sites evaluated in this study. The climate data presented in this table are mean values from 1960-1998 derived from the University of East Anglia Observational Climatology (New et al., 1999) and published in Malhi et al. (2004). Cumulative annual rainfall is given in $\mathrm{mm} \mathrm{yr}^{-1}$, dry season length (DSL) in months, corresponds to the sum of consecutive months with rainfall $<100 \mathrm{~mm} \mathrm{month}^{-1}$, and temperature is the mean annual temperature (MAT) in Celsius degrees.

\begin{tabular}{|c|c|c|c|c|c|c|c|}
\hline \multicolumn{5}{|c|}{ Study sites } & \multicolumn{3}{|c|}{ Climate } \\
\hline \multirow[t]{2}{*}{ RAINFOR sites code } & \multirow[t]{2}{*}{ Name } & \multirow[t]{2}{*}{ Country } & \multicolumn{2}{|c|}{ Location } & \multirow{2}{*}{$\frac{\text { Rainfall }}{\mathrm{mm} \mathrm{yr}^{-1}}$} & \multirow{2}{*}{$\frac{\text { DSL }}{\text { months }}$} & \multirow{2}{*}{$\frac{\text { MAT }}{\text { Celsius degrees }}$} \\
\hline & & & Lat & Long & & & \\
\hline AGP-01 & Agua Pudre plot E & Colombia & -3.72 & -70.3 & 2723 & 0.0 & 25.5 \\
\hline AGP-02 & Agua Pudre plot U & Colombia & -3.73 & -70.4 & 2723 & 0.0 & 25.5 \\
\hline CAX-03 & Caxiuanã drought experiment control plot & Brazil & -1.72 & -51.5 & 2314 & 4.0 & 26.9 \\
\hline CAX-06 & Caxiuanã flux tower site & Brazil & -1.72 & -51.5 & 2314 & 4.0 & 26.9 \\
\hline CAX-08 & Caxiuanã Terra Preta site & Brazil & -1.72 & -51.5 & 2314 & 4.0 & 26.9 \\
\hline MAN-05 & Manaus & Brazil & -2.5 & -60.0 & 2272 & 3.0 & 27.1 \\
\hline TAM-05 & Tambopata RAINFOR plot 3 & Peru & -12.8 & -69.7 & 2417 & 3.5 & 25.2 \\
\hline TAM-06 & Tamboapata RAINFOR plot 4 & Peru & -12.9 & -69.8 & 2417 & 3.5 & 25.2 \\
\hline TAP-04 & Tapajós flux tower site & Brazil & -2.5 & -55.0 & 1968 & 4.5 & 26.1 \\
\hline ZAR-01 & Zafire, Varillal & Colombia & -4.0 & -69.9 & 2723 & 0.0 & 25.5 \\
\hline
\end{tabular}

we also compiled data on leaf nitrogen and phosphorus concentrations ( $\mathrm{N}_{\text {leaf }}$ and $\mathrm{P}_{\text {leaf }}$, respectively; Fyllas et al., 2009), soil types, following the WRB soil taxonomy to be consistent with Quesada et al. (2009b), soil texture (clay content), and soil nitrogen and phosphorus concentrations $\left(\mathrm{N}_{\text {soil }}\right.$ and $\mathrm{P}_{\text {soil }}$, respectively; Quesada et al., 2009a). These data are shown in Table 2.

At Caxiuanã, Brazil, we surveyed three 1-ha plots $(100 \mathrm{~m} \times 100 \mathrm{~m})$. All plots are located at the Caxiuanã National Forest in Pará State. The plot CAX-06, is a tall primary forest ( $35 \mathrm{~m}$ height canopy) situated on a clay ferralsol (oxisol in USDA soil taxonomy) near a flux tower site (Malhi et al., 2009). The CAX-03 plot is a sandier site located $2 \mathrm{~km}$ to further south, which was the control plot for a drought experiment (Metcalfe et al., 2007a). The Terra Preta site (CAX-08) is a late successional forest on an ArchaeoAnthrosol (this classification was modified from the WRB soil taxonomy by Kampf et al. (2003) to encompass the variability of Terra Preta soils in Amazonia). The CAX-08 site is located about $15 \mathrm{~km}$ to the south of the primary study area, by the edge of a large river bay.

At Tambopata, Peru, we surveyed two pre-existing longterm 1-ha plots $(100 \mathrm{~m} \times 100 \mathrm{~m})$ located at the Tambopata Biological Reserve, in Madre de Dios Region. The plot TAM05 was set up on relatively infertile Pleistocene cambisols (inceptsols in USDA soil taxonomy), with an average canopy height of $30 \mathrm{~m}$. The plot TAM-06 was on alisols (ultisols in USDA soil taxonomy) on a fertile Holocene alluvial terrace. The canopy in this plot has the same average height as TAM05 , but a greater density of palms.

At Amacayacu, Colombia, our focus was on two 1-ha terra firme forest plots AGP-01 and AGP-02 (Jiménez et al., 2009). Both are located at the Amacayacu National Natural Park, near the border between Colombia, Brazil and Peru. The plots were set up in an area of primary old-growth forest, with a $25 \mathrm{~m}$ height canopy, on relatively fertile clay plinthosols (aquic entisols in USDA soil taxonomy).

At Zafire, Colombia our focus was on a 1-ha plot located on a white sand site, ZAR-01 (Jiménez et al., 2009). This is part of the Rio Calderón Forest Reserve, around $50 \mathrm{~km}$ east of the Amacayacu site. The plot was set up in an area of primary forest on white sand podzol (spodosol in the USDA soil taxonomy), locally known as Varillal. This forest is shorter than the forest at Amacayacu, with an average height of $20 \mathrm{~m}$. This forest type is scarce in western Amazonia but more frequent in the Guyana Shield and is similar to the formations along the Rio Negro. The soil in our plot has an impermeable hardpan layer at $\sim 100 \mathrm{~cm}$ depth (Jiménez et al., 2009).

At Tapajós, Brazil, we focus on the sites reported by Malhi et al. (2009). The main site is the $\mathrm{km} 67$ flux tower (TAP04, Hutyra et al., 2007; Saleska et al., 2003) and its vicinity. This site is located within the boundaries of the Tapajós National Forest in Pará State. The plots are established in old-growth forest with canopy height around $35 \mathrm{~m}$. The soils are very clay-rich Belterra clay ferralsols, interspersed with sandier soil patches. The key plots are four 1-ha transects established in 1999 immediately to the east of the tower (Rice et al., 2004; Pyle et al., 2008).

At Manaus, Brazil, the study sites were also focus on the sites reported in Malhi et al. (2009). The main sites are the K34 flux tower site (Araújo et al., 2002), and the various studies that have been conducted in its vicinity. The plots are stablished in old-growth Terra Firme forests on clay-rich ferrasols, extensively dissected by river valleys hosting lower biomass forest on frequently waterlogged podzols. The key forest plots in the area are the three 1-ha "Bionte" plots on the plateaux, providing annual census data since 1989 , and the two 5-ha $(20 \times 2500 \mathrm{~m})$ "Jacaranda" transect plots that drape across the plateau-valley landscape. 
Table 2. Leaf nutrient concentration $\left(\mathrm{mg} \mathrm{g}^{-1}\right)$ and soil available phosphorus concentration $\left(\mathrm{mg} \mathrm{kg}^{-1}\right)$, nitrogen concentration $(\%)$ and clay content (\%) for the ten Amazonian sites evaluated in this study. Leaf data are derived from Fyllas et al. (2009) and soil data from Quesada et al. (2009b). Note that the soil type is in accordance with the World Reference Base soil classification system (WRB).

\begin{tabular}{|c|c|c|c|c|c|c|}
\hline \multirow{2}{*}{ RAINFOR code } & \multicolumn{2}{|c|}{ Leaf nutrient } & \multicolumn{4}{|l|}{ Soil } \\
\hline & Nitrogen & Phosphorus & Type & Clay & Nitrogen & Phosphorus \\
\hline AGP-01 & 20.87 & 1.06 & Endostagnic Plinthosol (Alumic, Hyperdystric) & 42.12 & 0.16 & 25.36 \\
\hline AGP-02 & 19.17 & 0.96 & Endostagnic Plinthosol (Alumic, Hyperdystric) & 43.10 & 0.16 & 25.43 \\
\hline CAX04 & 20.63 & 0.55 & Vetic Acrisol (Alumic, Hyperdystric) & 16.30 & $0.07^{\mathrm{b}}$ & $12.31^{\mathrm{b}}$ \\
\hline CAX-06 & 19.13 & 0.53 & Geric Acric Ferralsol (Alumic, Hyperdystric,Clayic) & 47.53 & 0.13 & $12.31^{\mathrm{b}}$ \\
\hline CAX-08 & & & Hortic Archaeo-Anthrosol (Ebonic, Clayic, Mesothropic, Mesic, Ferralic) & 41.41 & 0.17 & 80.00 \\
\hline MAN-05 & $19.89^{\mathrm{a}}$ & $0.54^{\mathrm{a}}$ & Geric Ferralsol (Alumic, Hyperdystric, Clayic) & $66.21^{\mathrm{a}}$ & $0.16^{\mathrm{a}}$ & $7.28^{\mathrm{a}}$ \\
\hline TAM-05 & 23.99 & 1.05 & Haplic Cambisol (Alumic, Hyperdystric, Clayic) & 7.41 & 0.16 & 32.34 \\
\hline TAM-06 & 24.80 & 1.88 & Haplic Alisol (Hyperdystric, Siltic) & 9.66 & 0.17 & 33.06 \\
\hline TAP-04 & 22.58 & 0.75 & Geric Ferralsol (Alimic, Hyperdystric, Clayic, Xanthic) & 89.25 & 0.14 & 15.45 \\
\hline ZAR-01 & & & Ortseinc Podzol (Oxyaquic) & 0.64 & 0.11 & 14.36 \\
\hline
\end{tabular}

a Values are from MAN-05 plot.

b Values are averages from nearby plots CAX-01 and CAX-02.

For a more detailed view of the landscape attributes, such as vegetation type and structure, topography and plot locations, of many of these plots see Anderson et al. (2009).

\section{Materials and methods}

\subsection{Aboveground NPP}

\subsubsection{Litterfall}

At Caxiuanã and Tambopata, one litter trap with an area of $0.25 \mathrm{~m}^{2}(0.5 \mathrm{~m} \times 0.5 \mathrm{~m})$ was installed in the centre of each of the twenty-five 20 by $20 \mathrm{~m}$ subplots in the plots CAX06 and CAX-08 in August 2004. In January 2005 the same design was installed at Tambopata (TAM-05 and TAM-06). Litterfall in these four plots was collected every fifteen days from September 2004 to December 2006 in Caxiuanã and from February 2005 to December 2006 in Tambopata. Litterfall in the third 1-ha plot in Caxiuanã (CAX-03) was recorded monthly from November 2001 to December 2006 using twenty circular traps $\left(\right.$ area $=1 \mathrm{~m}^{2}$ ) randomly placed in November 2001.

At Amacayacu and Zafire one litter trap with an area of $0.50 \mathrm{~m}^{2}(0.5 \mathrm{~m} \times 1.0 \mathrm{~m})$ was installed in 2005 in the centre of each of the twenty-five 20 by $20 \mathrm{~m}$ subplots in the plots AGP-01, AGP-02 and ZAR-01. In all three sites litterfall was collected biweekly for two years at AGP-01 and AGP02 , and for 1.5 years at ZAR-01.

For all of these sites sites, traps were made with a PVC frame and a $1 \mathrm{~mm}$ nylon mesh and were placed at $1 \mathrm{~m}$ above the ground surface. Litter retrieved from the traps was immediately sun dried and subsequently dried in the laboratory oven at $60^{\circ} \mathrm{C}$ until constant weight. Each dried sample was separated into leaves, twigs $(<2 \mathrm{~cm}$ diameter), reproductive structures (flowers, fruit and seeds) and unidentified material, and weighed.

At Tapajós, litterfall values compiled by Malhi et al. (2009) were from: (1) Rice et al. (2004), who calculated fine litterfall from 30 circular mesh traps $(0.43 \mathrm{~m}$ diameter, $0.15 \mathrm{~m}^{2}$ ), randomly located throughout the 19.75 -ha survey area; (2) Silver et al. (2000), who estimated fine litterfall rates in six to ten $4 \mathrm{~m} \times 12 \mathrm{~m}$ plots, using six $0.9 \mathrm{~m}^{2}$ baskets per plot; and (3) Nepstad et al. (2002), who used $0.5 \mathrm{~m}^{2}$ traps at 100 points arranged as a regular grid within two 1-ha plots. At all sites litter was collected at biweekly intervals. For Manaus, following Malhi et al. (2009), we used the mean values from Luizão et al. (2004).

\subsubsection{Branch production}

The production of large branches was not measured in this experiment. For completeness of our NPP estimate we used a branchfall average rate for all plots of $1 \mathrm{MgCha}^{-1} \mathrm{yr}^{-1}$ based upon data from two studies carried out in Amazonia: one in Manaus that reported a rate of $0.4 \mathrm{MgCha}^{-1} \mathrm{yr}^{-1}$ (Chambers et al., 2001) and a second one in the Tapajós that estimated a branchfall rate of $1.6 \pm 0.8 \mathrm{MgC} \mathrm{ha}^{-1} \mathrm{yr}^{-1}$ (Nepstad et al., 2002). For the analysis of error propagation (see below) we used a conservative uncertainty $\pm 100 \%$ (Malhi et al., 2009). It is possible that sites with higher $\mathrm{NPP}_{\text {stem }}$ and also higher stem breakage in western Amazonia would have higher $\mathrm{NPP}_{\text {branch }}$ rates.

\subsubsection{Coarse woody biomass production}

Wood productivity $\left(\mathrm{NPP}_{\text {stem }}\right)$ was estimated by repeated censuses of tree diameters and stems newly recruiting into the $10 \mathrm{~cm}$ diameter size-class, taking into account taxon-specific variation in wood density. 
At Caxiuanã, the censuses at CAX-06 and CAX-08 were carried out from 2004-2006 with an average census interval of $0.78 \pm 0.11$ years (CAX-06) and $1.16 \pm 0.23$ years (CAX08). At CAX-03 recensuses took place annually from 20012006 (Metcalfe et al., 2009).

At Tambopata, a much longer time interval was available for both plots (TAM-05 and TAM-06). The censuses at TAM-05 were carried out from 1985 to 2005 with an average census interval of $2.79 \pm 0.50$ years, and at TAM06 from 1987 to 2005 with average census interval of $3.19 \pm 0.87$ years.

At Amacayacu and Zafire, plots AGP-01, AGP-02 and ZAR-01 censuses were carried out annually between 20042006 (Jiménez et al., 2009).

At Tapajós and Manaus we used values published in Malhi

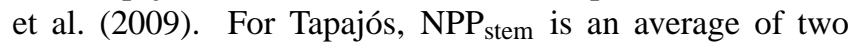
surveys at km 67 reported by Pyle et al. (2008) (20 ha in total), and for Manaus values are an average of the Bionte, Jacaranda and BDF plots (using the recent values from Pyle et al., 2008, for the latter).

For all plots the same methodology was applied to derive biomass and stem growth. Initially, for each plot the aboveground biomass (AGB, $\mathrm{kg}$ dry weight $\mathrm{ha}^{-1}$ ) of all trees with diameter at breast height $(\mathrm{DBH}) \geq 10 \mathrm{~cm}$, including palms, was calculated using the equation proposed by Chambers et al. (2001) for central Amazonian forests, and modified by Baker et al. (2004) to allow for variation in wood density (Eq. 4).

$$
\begin{aligned}
& \mathrm{AGB}=\sum_{1}^{n} \frac{\sigma_{i}}{0.67} \\
& \times\left\{\exp \left[0.33\left(\ln D_{i}\right)+0.933\left(\ln D_{i}\right)^{2}-0.122\left(\ln D_{i}\right)^{3}-0.37\right]\right\}
\end{aligned}
$$

where $D_{i}$ and $\sigma_{i}$ are, respectively, the diameter $(\mathrm{cm})$ and wood density $\left(\mathrm{g} \mathrm{cm}^{-3}\right)$ of tree $i, n$ is the number of stems per plot. To be consistent with other studies we considered the carbon fraction in the dry biomass to be 0.5 .

Following Malhi et al. (2004) we estimated the woody productivity for each plot at each census interval by subtracting the AGB of the surviving trees at second census $\left(t_{1}\right)$ by the first census $\left(t_{0}\right)$ and added to this total the AGB that of new recruits. However, variation in census intervals affects estimates of wood productivity, as trees that grew but died before the second census are missed. Specifically, estimates of wood productivity decrease approximately linearly with increasing census interval length. We therefore used the plot-specific census-interval correction proposed by Malhi et al. (2004), adjusted for AGB values instead of basal area (Phillips et al., 2009). The correction varies approximately as the square of the growth rate.

\subsection{Belowground NPP}

\subsubsection{Coarse root productivity}

Production of coarse roots is a very difficult term to quantify. For this study we assumed that the productivity per unit mass of all roots that are not included in the fine root productivity (i.e. roots $>2 \mathrm{~mm}$ diameter) is the same as the productivity of the above ground biomass and that belowground coarse root biomass is $21 \pm 3 \%$ of above-ground biomass (Malhi et al., 2009). Hence, $\mathrm{NPP}_{\text {coarseroot }}=0.21( \pm 0.03) \times \mathrm{NPP}_{\text {stem }}$. This may underestimate $\mathrm{NPP}_{\text {coarseroot }}$ as the productivity of smaller roots is likely to be greater than the productivity of the massive structural roots.

\subsubsection{Fine root productivity}

This term was directly quantified in CAX-06, CAX-08, CAX-03, TAM-05, TAM-06, AGP-01, AGP-02 and ZAR-01 using the ingrowth cores technique (Vogt et al., 1998; Steingrobe et al., 2000; Hendricks et al., 2006; Metcalfe et al., 2008). Fine-roots considered here are defined as $<2 \mathrm{~mm}$ in diameter.

At Caxiuanã and Tambopata, sixteen root-free ingrowth cores with an area of $154 \mathrm{~cm}^{2}$ and depth of $30 \mathrm{~cm}$ were installed in each plot (CAX-06, CAX-08, CAX-03, TAM-05, TAM-06) in a $20 \mathrm{~m}$ by $20 \mathrm{~m}$ regular grid, $20 \mathrm{~m}$ from the edge of the plot. Ingrowth cores were installed at the beginning of November 2004 in the Caxiuanã plots (CAX-06, CAX-08, CAX-03) and at the beginning of June 2005 in the Tambopata plots (TAM-05 and TAM-06). At each sampling point, one soil core were extracted, keeping the soil layers separated to avoid the transference of soil with high nutrient content from the top to the bottom layers. Roots were manually removed and the remaining soil was reinserted into the hole surrounded by a $1 \mathrm{~cm}$ plastic mesh bag. This procedure was repeated every three months in all plots from November 2004 to November 2005 in Caxiuanã and from June 2005 to April 2007 in Tambopata. At each three-month interval ingrowth cores were removed from the soil and all fine roots manually extracted following the method described by Metcalfe et al. (2007c) which corrects for underestimates in, particularly fine, root mass. Afterwards, the root free soil cores were reinserted into the same holes. Roots were then dried at $60^{\circ} \mathrm{C}$ until constant weight, subsequently cleaned for removal of soil particles and weighed to determine dry root mass produced during each three-month interval.

At Amacayacu, thirteen ingrowth cores and at Zafire fourteen ingrowth cores with an area of $23.6 \mathrm{~cm}^{2}$ and depth of $20 \mathrm{~cm}$ were installed in the plots AGP-01, AGP-02 and ZAR01 (Jiménez et al., 2009). The ingrowth cores at AGP-01 and AGP-02 were installed at three different dates: February 2004 (Experiment 1), using cores surrounded by a $4 \mathrm{~mm}^{2}$ mesh bag, and September 2004 (Experiment 2) and February 2006 (Experiment 3), using cores with no mesh. At 
plot ZAR-01 installation took place in September 2004 (Experiment 2) and February 2006 (Experiment 3) using no mesh cores. The collection, extraction and processing of the roots were fairly similar to the one presented for Caxiuanã. Detailed description of the methods is given in Jiménez et al. (2009), so here we give a summary of the methods. Experiment 1 was carried out from February 2004 to July 2006, Experiment 2 from September 2004 to July 2006 and Experiment 3 from February 2006 to December 2006. The first collection was carried out 5-7 months after installation of the ingrowth cores for the three experiments. Subsequent collections were carried out 2-4 months after the re-installation of the root-free ingrowth cores. For the present study we used an average value of all experiments to better represent inter and intra-annual variability of fine-root production.

At Tapajós, we used the values of fine root production reported in Malhi et al. (2009). Fine root production at this site was calculated by Silver et al. (2000) using the sequential coring method at TAP-04, sampling $0-10 \mathrm{~cm}$ depth with a $6 \mathrm{~cm}$ diameter corer every two months for two years. Subsequently, root production was estimated using a compartment flow model (Sanantonio and Grace, 1987), with decay rates calculated directly from a trenching experiment. The study was conducted in six plots approximately $4 \mathrm{~m} \times 12 \mathrm{~m}$ in size.

All data from Caxiuanã, Tambopata, Amacayacu, Zafire and Tapajós were adjusted following Malhi et al. (2009) to account for root production to one-meter depth. No existing data on fine-root production were found for Manaus. Therefore, an average value of plots on similar soil types (acrisols and ferrasols) at CAX-06, CAX-03, TAP-04 was used to estimate fine-root production in this site.

In addition, we compiled fine root stand biomass data, adjusted to one meter depth, in order to estimate fine root turnover (stand biomass/productivity) as a complementary measure of fine root dynamics across the fertility gradient. For Caxiuanã, values of fine root stand biomass for all the three plots are reported in Metcalfe et al. (2008). For the two plots at Amacayacu and the one at Zafire, values of fine root biomass are from Jiménez et al. (2009). For Tapajós we used the values of fine root turnover reported by Silver et al. (2005). Fine root stand biomass for Tambopata was directly estimated in this study (TAM- $05=7.7 \mathrm{MgCha}^{-1}$ and TAM-06 $=5.0 \mathrm{Mg} \mathrm{C} \mathrm{ha}^{-1}$ ).

\subsection{Soil and leaf data}

The soil available phosphorus and nitrogen concentrations $(0-30 \mathrm{~cm}$ depth) and texture used in this study were obtained from Quesada et al. (2009c), and methods are only briefly summarized here. For each 1-ha plot, five to twelve soil cores were collected using an undisturbed soil sampler (Eijkelkamp Agrisearch Equipment BV, Giesbeek, The Netherlands). All sampling was done following a standard protocol (see http://www.geog.leeds.ac.uk/projects/rainfor/ projdocs.html).
Soil samples were air-dried and had roots, detritus, small rocks and particles over $2 \mathrm{~mm}$ removed. Samples were then analysed for: (1) complete phosphorus fractionation (modified from Hedley et al. 1982), (2) nitrogen (Pella, 1990; Nelson and Sommers, 1996), and (3) particle size analysis using the Boyoucos method (Gee and Bauder, 1986).

In this study we used the readily available P, which is defined as sum of the P immediately accessible in solution (measured as the resin P), plus that organic and inorganic phosphorus that can be extracted by bicarbonate. It appears a good measure of the phosphorus that plant roots are able to extract at little cost, and hence a good measure of plant $\mathrm{P}$ availability (Quesada et al., 2009a).

The leaf phosphorus and nitrogen concentrations used in this study were obtained from Fyllas et al. (2009). Leaf sampling and analysis protocols are described in detail in Lloyd et al. (2009). In brief, 12 to 40 trees per 1 ha plot were randomly selected and leaf samples for each tree were collected from full sun canopy positions with the help of a tree climber. Leaves were cleaned and dried, milled and stored for laboratory analysis.

Samples from Peruvian and Colombian sites were analysed at the Central Analytical and Stable Isotopes Facilities at the Max-Planck Institute for Biogeochemistry (MPIBGC) in Jena, Germany. Samples from Brazilian sites were analysed for phosphorus at Instituto Nacional de Pesquisas da Amazônia (INPA) and for nitrogen at Empresa Brasileira de Pesquisas Agropecuárias (EMBRAPA), both in Manaus, Brazil. Leaf nitrogen concentrations were determined in the Brazilian and German laboratories using finely ground plant material in an elemental analyser (Elementar Analysensysteme, Hanau, Germany). At INPA, phosphorus concentrations were determined after acid digestion of the leaf material in a UV visible spectrophotometer (Model 1240, Shimadzu, Kyoto, Japan). At the MPI-BGC sample extracts were analysed by an ICP-OES (Model Optima 3300 DV, Perkin Elmer, Norwalk, CT, USA). For all chemical analyses the equipments were inter-calibrate for consistency of the results.

\subsection{Propagation of uncertainties and data analyses}

All uncertainty estimates throughout the text are reported as standard errors assuming normal distributions. Uncertainties are propagated by quadrature of absolute errors (Malhi et al., 2009). Therefore, if $y$ is the sum of a number of variables $x_{1} \ldots x_{i} \ldots x_{n}$, each with associated uncertainty $\Delta x_{i}$, then the absolute uncertainties are propagated in quadrature (Eq. 5):

$(\Delta y)^{2}=\sum_{i=1}^{n}\left(\Delta x_{i}\right)^{2}$

This assumes that uncertainties can be considered to be independent and normally distributed. It is important to note that uncertainty values represent uniquely the precision of measurements and that biases related to methodological issues were not accounted for in the error analysis due to the lack 
Table 3. Net primary productivity of each subcomponent of the total NPP ( $\left.\mathrm{NPP}_{\text {total }}\right)$ for each one of the studied sites. The NPP values are given in $\mathrm{MgC} \mathrm{ha}^{-1} \mathrm{yr}^{-1}$ with its associated standard error (S.E.). Note that for Manaus an average value of plots on similar soil types (acrisols and ferrasols) at CAX-06, CAX-03, TAP-04 was used to estimate fine-root production in this site.

\begin{tabular}{|c|c|c|c|c|c|c|c|c|c|c|c|c|c|c|c|c|c|c|c|c|}
\hline \multirow[t]{2}{*}{ Site } & \multicolumn{2}{|c|}{ CAX-06 } & \multicolumn{2}{|c|}{ CAX-03 } & \multicolumn{2}{|c|}{ CAX-08 } & \multicolumn{2}{|c|}{ TAP-04 } & \multicolumn{2}{|c|}{ MAN-05 } & \multicolumn{2}{|c|}{ TAM-05 } & \multicolumn{2}{|c|}{ TAM-06 } & \multicolumn{2}{|c|}{ AGP-01 } & \multicolumn{2}{|c|}{ AGP-02 } & \multicolumn{2}{|c|}{ ZAR-01 } \\
\hline & NPP & S.E. & NPP & S.E. & NPP & S.E. & NPP & S.E. & NPP & S.E. & NPP & S.E. & NPP & S.E. & NPP & S.E. & NPP & S.E. & NPP & S.E. \\
\hline $\mathrm{NPP}_{\text {canopy }}$ & 3.8 & 0.10 & 3.5 & 0.10 & 5.4 & 0.20 & 6.5 & 0.70 & 3.6 & 0.70 & 5.6 & 0.30 & 4.6 & 0.24 & 3.9 & 0.20 & 3.7 & 0.20 & 2.7 & 0.10 \\
\hline $\mathrm{NPP}_{\text {branch }}$ & 1.0 & 1.00 & 1.0 & 1.00 & 1.0 & 1.00 & 1.0 & 1.00 & 1.0 & 1.00 & 1.0 & 1.00 & 1.0 & 1.00 & 1.0 & 1.00 & 1.0 & 1.00 & 1.0 & 1.00 \\
\hline $\mathrm{NPP}_{\text {stem }}$ & 1.7 & 0.21 & 2.6 & 0.20 & 2.5 & 0.26 & 3.8 & 0.07 & 2.6 & 0.06 & 2.8 & 0.24 & 2.6 & 0.42 & 3.4 & 0.30 & 3.8 & 0.30 & 1.3 & 0.30 \\
\hline $\mathrm{NPP}_{\text {coarseroot }}$ & 0.4 & 0.04 & 0.4 & 0.03 & 0.5 & 0.05 & 1.0 & 0.30 & 0.8 & 0.20 & 0.6 & 0.10 & 0.6 & 0.09 & 0.7 & 0.06 & 0.8 & 0.06 & 0.3 & 0.06 \\
\hline $\mathrm{NPP}_{\text {fineroot }}$ & 3.9 & 0.40 & 4.0 & 0.90 & 7.6 & 0.93 & 2.0 & 0.30 & 3.3 & 0.34 & 6.8 & 1.00 & 4.8 & 0.57 & 2.2 & 0.40 & 2.2 & 0.40 & 3.9 & 0.68 \\
\hline $\mathrm{NPP}_{\text {voc }}$ & 0.1 & 0.13 & 0.1 & 0.13 & 0.1 & 0.13 & 0.1 & 0.13 & 0.1 & 0.13 & 0.1 & 0.13 & 0.1 & 0.10 & 0.1 & 0.10 & 0.1 & 0.10 & 0.1 & 0.10 \\
\hline $\mathrm{NPP}_{\mathrm{AG}}$ & 6.7 & 1.04 & 7.2 & 1.03 & 9.0 & 1.06 & 11.4 & 1.20 & 7.3 & 1.23 & 9.5 & 1.08 & 8.4 & 1.11 & 8.4 & 1.07 & 8.6 & 1.07 & 5.1 & 1.05 \\
\hline $\mathrm{NPP}_{\mathrm{BG}}$ & 4.2 & 0.40 & 4.4 & 0.90 & 8.1 & 0.93 & 3.0 & 0.40 & 4.1 & 0.40 & 7.4 & 1.00 & 5.4 & 0.58 & 3.0 & 0.41 & 3.0 & 0.40 & 4.2 & 0.68 \\
\hline $\mathrm{NPP}_{\text {total }}$ & 10.9 & 1.11 & 11.6 & 1.37 & 17.0 & 1.41 & 14.4 & 1.30 & 11.4 & 1.29 & 16.9 & 1.47 & 13.8 & 1.26 & 11.3 & 1.14 & 11.7 & 1.14 & 9.3 & 1.26 \\
\hline
\end{tabular}

of available information. Probable sources of unaccounted errors are discussed throughout the text and their potential magnitude is quantified in Clark et al. (2001a).

All the results of the estimated fluxes reported in this study are in $\mathrm{MgCha}^{-1} \mathrm{yr}^{-1} .1 \mathrm{MgCha}^{-1} \mathrm{yr}^{-1}$ is equal to $100 \mathrm{~g} \mathrm{C} \mathrm{m}^{-2} \mathrm{yr}^{-1}$, or $0.264 \mu \mathrm{mol} \mathrm{C} \mathrm{m}{ }^{-2} \mathrm{~s}^{-1}$.

The partitioning of $\mathrm{NPP}_{\text {total }}$ into its subcomponents, the relationship between $\mathrm{NPP}_{\text {canopy }}$ and $\mathrm{NPP}_{\text {stem }}$ and the effect of soil and leaf nutrient status and soil texture on patterns of above- and below-ground NPP across the ten Amazonian sites was assessed using linear regression analysis. In addition, we ran a set of correlation analyses, including the Pearson product-moment, Spearman rank and Kendall tau, between $\mathrm{NPP}_{\text {total }}, \mathrm{NPP}_{\mathrm{AG}}$, and $\mathrm{NPP}_{\mathrm{BG}}$ and climate and environmental variables. We opted for presenting the results of both parametric and non-parametric tests because of our small sample size ( $n$ between 7 and 9). A $z$-test was applied, when necessary, to compare mean values and regression slopes. For the regression analyses, plots AGP-01 and AGP-02 were merged into a single plot average to avoid spatial autocorrelation issues. Moreover, for the analyses where below-ground productivity is explicitly taken into account, plot MAN-05 was removed as plot level estimates of $\mathrm{NPP}_{\text {fineroot }}$ is inexistent.

\section{Results}

\subsection{Patterns of net primary productivity across the sites}

The estimated $\mathrm{NPP}_{\text {total }}$ for the ten plots analysed ranged between $9.3 \pm 1.3 \mathrm{MgCha}^{-1} \mathrm{yr}^{-1}$ at the white sand plot, ZAR-01, and $17.0 \pm 1.4 \mathrm{MgCha}^{-1} \mathrm{yr}^{-1}$ at the Terra Preta site, CAX-08 (Table 3). Similarly, the above-ground NPP $\left(\mathrm{NPP}_{\mathrm{AG}}\right)$ has its lowest value at ZAR-01 (5.1 $\left.\pm 1.1 \mathrm{MgCha}^{-1} \mathrm{yr}^{-1}\right)$, however, the highest $\mathrm{NPP}_{\mathrm{AG}}$ was estimated for the Tapajós site, TAP-04

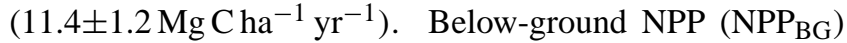

varied between $3.0 \pm 0.4 \mathrm{Mg} \mathrm{Cha}^{-1} \mathrm{yr}^{-1}$ at TAP-04, AGP-01 and AGP-02 and $8.1 \pm 0.9 \mathrm{MgCha}^{-1} \mathrm{yr}^{-1}$ at CAX-08.

To investigate if NPP in our analysis presents the same trend as proposed by Malhi et al. (2004), where plots on more fertile soils in western Amazonia have greater $\mathrm{NPP}_{\text {stem }}$, we ordered the data presented in Table 3 by increasing soil available phosphorus (Fig. 2). As expected, the more fertile sites sit to the west, with exception of the "artificially" fertile Terra Preta site, CAX-08 in the east (the most fertile of all our sites), and the anomalous white sand ZAR-01 in the

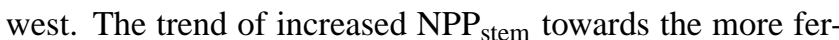
tile sites, as suggested by Malhi et al. (2004) is not obvious in our smaller dataset. However, there is a tendency of greater $\mathrm{NPP}_{\mathrm{AG}}, \mathrm{NPP}_{\mathrm{BG}}$ and $\mathrm{NPP}_{\text {total }}$ towards the more fertile sites, which will be further explored in the following sections.

$\mathrm{NPP}_{\text {canopy }}$ varied between $2.7 \pm 1.1 \mathrm{MgCha}^{-1} \mathrm{yr}^{-1}$ at the white sand plot (ZAR-01) and $6.5 \pm 0.7 \mathrm{MgCha}^{-1} \mathrm{yr}^{-1}$ at Tapajós (TAP-04) (Fig. 3). $\mathrm{NPP}_{\text {stem }}$ varied between $1.3 \pm 0.3 \mathrm{Mg} \mathrm{Cha}^{-1} \mathrm{yr}^{-1}$ at the white sand plot (ZAR-01) and $3.8 \pm 0.1 \mathrm{MgCha}^{-1} \mathrm{yr}^{-1}$ at Tapajós (TAP-04), while

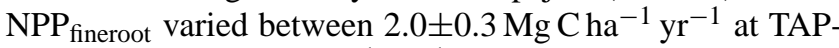
04 and $7.6 \pm 0.9 \mathrm{Mg} \mathrm{Cha}^{-1} \mathrm{yr}^{-1}$ at the anthrosol CAX-08.

With the notable exception of the TAP-04 site, NPP was greater in the more fertile sites. $\mathrm{NPP}_{\text {stem }}$, on the other hand, is maximal in the plots TAP-04, AGP-01 and AGP-02, which are in the middle of our soil fertility gradient. Conversely, these same plots have the lowest $\mathrm{NPP}_{\text {fineroot }}$ among all plots. Overall, sites on the most fertile soils tended to have higher $\mathrm{NPP}_{\text {fineroot }}$, with values being similarly high in the very fertile anthrosol CAX-08 and in the moderately fertile cambisols and alisols at Tambopata (TAM-05 and TAM06) (Fig. 3).

The TAP-04 site has distinct patterns of extremely high $\mathrm{NPP}_{\mathrm{AG}}$ and low $\mathrm{NPP}_{\mathrm{BG}}$ in comparison to other plots with similar soil and climate characteristics. The forest at Tapajós is allocating a disproportional amount of $\mathrm{C}$ to above-ground biomass gain, which may be a consequence of large-scale recent natural disturbance or chronic on-going mortality (see 


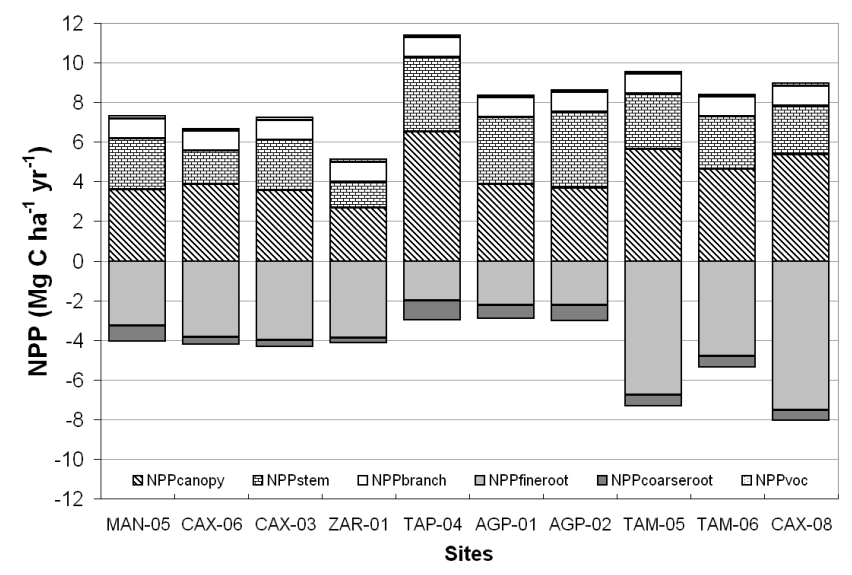

Fig. 2. The net primary productivity of the ten studied sites. Bars correspond to the $\mathrm{NPP}_{\text {total }}$ of each site. Each bar gives the absolute contribution of each subcomponent to the $\mathrm{NPP}_{\text {total }}$. Negative values were used to represent the below-ground productivity, and to obtain the correct positive values below-ground components must be multiplied by -1 . Sites are ordered in an increased order of soil available phosphorus (Table 2) and all values are in $\mathrm{MgC} \mathrm{ha}^{-1} \mathrm{yr}^{-1}$.

discussion section). For subsequent analyses we therefore present some of the results both with and without the Tapajós site.

\subsection{Partitioning of $\mathrm{NPP}_{\text {total }}$ into its subcomponents}

The regression analysis showed that there is a significant increase of both $\operatorname{NPP}_{\mathrm{AG}}\left(R^{2}=0.58, p=0.02, n=9\right)$ and $\mathrm{NPP}_{\mathrm{BG}}$ $\left(R^{2}=0.55, p=0.03, n=8\right)$ with increasing $\mathrm{NPP}_{\text {total }}$ (Fig. $4 \mathrm{a}$ ). This relationship becomes much more significant without the plot TAP-04 for both $\mathrm{NPP}_{\mathrm{AG}}\left(R^{2}=0.76, p=0.005, n=8\right)$ and $\mathrm{NPP}_{\mathrm{BG}}\left(R^{2}=0.83, p=0.004, n=7\right)$ (Fig. 4a). This indicates that the partitioning pattern may differ between old-growth systems in "quasi-equilibrium" and recently disturbed forests (Malhi et al., 2009).

There is no significant difference (z-test) in the slopes of the relation of $\mathrm{NPP}_{\mathrm{AG}}$ and $\mathrm{NPP}_{\mathrm{BG}}$ with $\mathrm{NPP}_{\text {total }}$ whether or not TAP-04 is included. This is indicative of fairly invariant allocation between $\mathrm{NPP}_{\mathrm{AG}}$ and $\mathrm{NPP}_{\mathrm{BG}}$ across the broad $\mathrm{NPP}_{\text {total }}$ gradient.

By dividing the NPP of each component by $\mathrm{NPP}_{\text {total }}$ we quantified the relative proportion of $\mathrm{NPP}_{\text {total }}$ allocated to each component. Our results show that the ten Amazonian forests studied allocate between 53\% (CAX-08) and $79 \%$ (TAP-04) of the $\mathrm{NPP}_{\text {total }}$ into $\mathrm{NPP}_{\mathrm{AG}}$ and between $21 \%$ (TAP-04) and 37\% (CAX-08) into NPP $\mathrm{BG}_{\mathrm{BG}}$. We found that $\mathrm{NPP}_{\text {canopy }}, \mathrm{NPP}_{\text {stem }}$ and $\mathrm{NPP}_{\text {fineroot }}$ are on average $33.5 \pm 1.5 \%, 21.3 \pm 2.2 \%, 31.4 \pm 3.5 \%$ of the $\mathrm{NPP}_{\text {total }}$, respectively.

The relative proportion of NPP allocated to below-ground $\left(\mathrm{NPP}_{\mathrm{BG}} / \mathrm{NPP}_{\text {total }}\right)$ was not significantly related to $\mathrm{NPP}_{\text {total }}$ as suggested above by the analysis of the regression slopes.
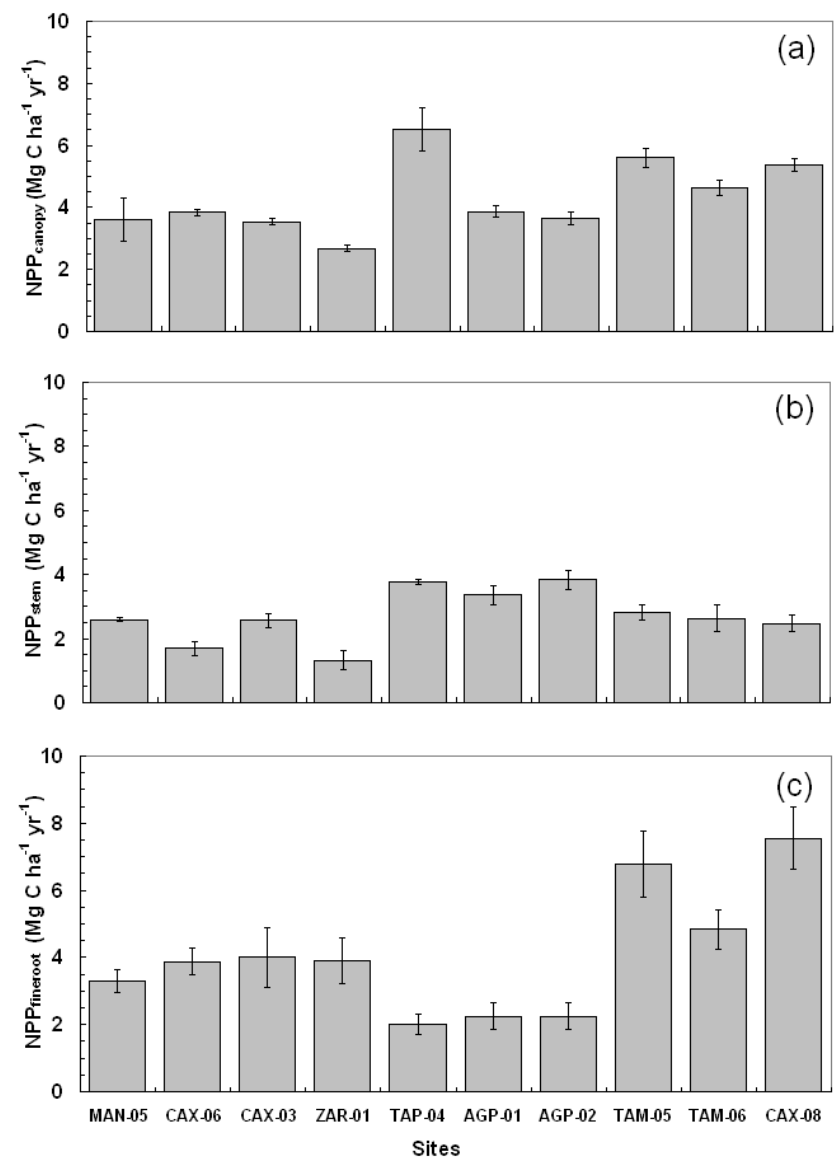

Fig. 3. The net primary productivity of the major subcomponents of the $\mathrm{NPP}_{\text {total }}$ in the ten studied sites: (a) fine litter production; (b) stem production; and (c) fine root production. All values are in $\mathrm{MgC} \mathrm{ha}^{-1} \mathrm{yr}^{-1}$ with their respective standard errors. Sites are ranked by increasing soil available phosphorus (Table 2).

However, Fig. $4 \mathrm{~b}$ shows that the proportion of $\mathrm{NPP}_{\text {total }}$ allocated below-ground is inversely correlated with the total amount of $\mathrm{C}$ allocated to stem growth $\left(R^{2}=0.58, p=0.03\right.$, $n=8)$. However, this result could be somewhat biased by the fact that our estimation of $\mathrm{NPP}_{\text {coarseroot }}$ accounted in the estimation of $\mathrm{NPP}_{\mathrm{BG}}$ is calculated as a proportion of $\mathrm{NPP}_{\text {stem }}$. Even using only the proportion allocated to fine root instead of the total below-ground allocation, which is an independent measurement, the relationship is strong $\left(R^{2}=0.61, p=0.02\right.$, $n=8)$.

$\mathrm{NPP}_{\text {total }}$ is very strongly correlated with $\mathrm{NPP}_{\text {canopy }}$ $\left(R^{2}=0.73, p=0.003, n=9\right)$, especially when TAP-04 is excluded $\left(R^{2}=0.98, p<0.001, n=8\right)$. As $\mathrm{NPP}_{\text {canopy }}$ is a major component of $\mathrm{NPP}_{\text {total }}$ the result of the previous analysis may be redundant. To check the validity of this test we regressed $\mathrm{NPP}_{\text {canopy }}$ against the result of the difference between $\mathrm{NPP}_{\text {total }}$ and $\mathrm{NPP}_{\text {canopy }}$. The correlation between these two completely independent variables was significant when excluding TAP-04 $\left(R^{2}=0.38, n=9, p=0.08 ; R^{2}=0.90\right.$, 

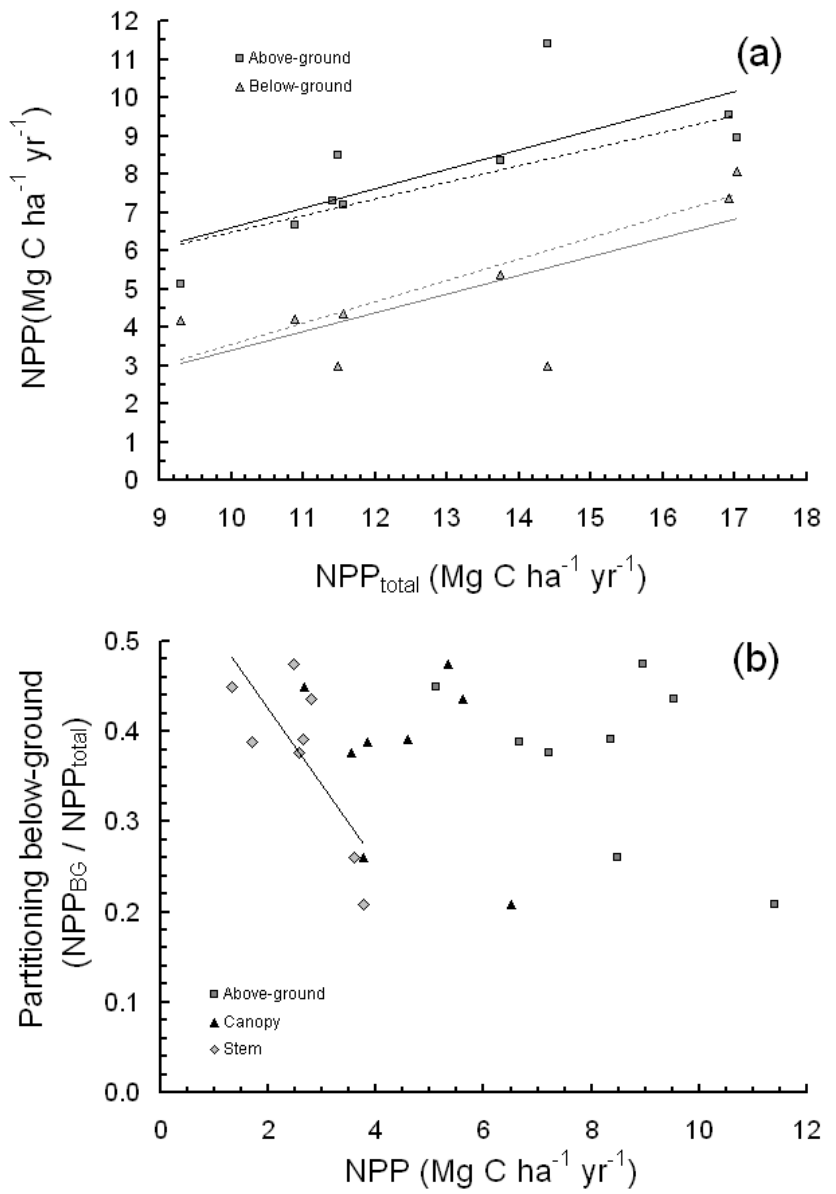

Fig. 4. (a) The relationship between the above-ground NPP and the total NPP (dark grey squares), with the regression lines for all data (black) and without the Tapajós site (black dashed). The linear regression equations are (all data $-\mathrm{NPP}_{\mathrm{AG}}=0.51$ $( \pm 0.16) \times \mathrm{NPP}_{\text {total }}+1.55( \pm 2.17), n=9, R^{2}=0.58, p=0.02$; without Tapajós $-\mathrm{NPP}_{\mathrm{AG}}=0.43( \pm 0.10) \times \mathrm{NPP}_{\text {total }}+2.15( \pm 1.32), n=8$, $\left.R^{2}=0.76, p=0.005\right)$ and the relationship between below-ground NPP and the total NPP (light grey triangles), with the regression lines for all site (grey) and without the Tapajós site (grey dashed). The linear regression equations are (all data $-\mathrm{NPP}_{\mathrm{AG}}=0.49$ $( \pm 0.18) \times \mathrm{NPP}_{\text {total }}-1.55( \pm 2.43), n=8, R^{2}=0.55, p=0.03$; without Tapajós $-\mathrm{NPP}_{\mathrm{BG}}=0.55( \pm 0.11) \times \mathrm{NPP}_{\text {total }}-2.05( \pm 1.49), n=7$, $\left.R^{2}=0.83, p=0.004\right)$. (b) The relationship between the proportion of $\mathrm{NPP}_{\text {total }}$ allocated below-ground $\left(\mathrm{NPP}_{\mathrm{BG}} / \mathrm{NPP}_{\text {total }}\right)$ and the $\mathrm{NPP}_{A G}$ (dark grey squares), $\mathrm{NPP}_{\text {canopy }}$ (black triangles) and

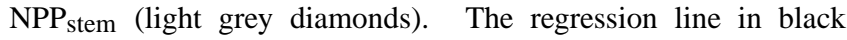
indicates a significant relationship between $\left(\mathrm{NPP}_{\mathrm{BG}} / \mathrm{NPP}_{\text {total }}\right)$ and $\mathrm{NPP}_{\text {stem }}\left(\left(\mathrm{NPP}_{\mathrm{BG}} / \mathrm{NPP}_{\text {total }}\right)=-0.08( \pm 0.03) \times \mathrm{NPP}_{\text {stem }}+0.59\right.$ ( \pm 0.08$), n=8, R^{2}=0.58, p=0.03$ ).

$n=8, p<0.001$, with and without considering the Tapajós site respectively), reinforcing the significance of the correlation between $\mathrm{NPP}_{\text {total }}$ and $\mathrm{NPP}_{\text {canopy }}$. Moreover, $\mathrm{NPP}_{\text {total }}$ is also significantly correlated with $\mathrm{NPP}_{\text {fineroot }}$ when excluding the site TAP-04 $\left(R^{2}=0.44, p=0.07\right.$ and $R^{2}=0.77, p<0.009$, with and without the Tapajós site respectively) (Fig. 5a, c). Interestingly, stem production did not vary much along the

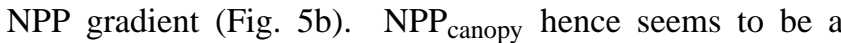
strong predictor of $\mathrm{NPP}_{\text {total }}$ in old-growth, low disturbance Amazonian forests with the inverted linear regression being $\mathrm{NPP}_{\text {total }}=2.81( \pm 0.25) \times \mathrm{NPP}_{\text {canopy }}-1.22( \pm 1.06)$.

In summary, the sites with higher $\mathrm{NPP}_{\text {total }}$ tend to have higher $\mathrm{NPP}_{\mathrm{AG}}$ (mainly higher $\mathrm{NPP}_{\text {canopy }}$ ) and also higher $\mathrm{NPP}_{\mathrm{BG}}$ (mainly $\mathrm{NPP}_{\text {fineroot}}$ ). The fractional allocation of $\mathrm{NPP}_{\text {total }}$ to below-ground is invariant across the $\mathrm{NPP}_{\text {total }}$ gradient but varies inversely with $\mathrm{NPP}_{\text {stem }}$, decreasing from $47 \%$ when $\mathrm{NPP}_{\text {stem }}=2.5 \mathrm{Mg} \mathrm{Cha}^{-1} \mathrm{yr}^{-1}$ (CAX-08) to $21 \%$ when $\mathrm{NPP}_{\text {stem }}=3.8 \mathrm{MgC} \mathrm{ha}^{-1} \mathrm{yr}^{-1}$ (TAP-04).

\subsection{Relationship between $\mathrm{NPP}_{\text {canopy }}$ and $\mathrm{NPP}_{\text {stem }}$}

Malhi et al. (2004) reported a strong proportionality between $\mathrm{NPP}_{\text {canopy }}$ and $\mathrm{NPP}_{\text {stem. }}$. They combined data on litterfall and stem production from sites investigated in their study and published by Clark et al. (2001a) and found that: $\mathrm{NPP}_{\text {stem }}=1.73( \pm 0.09) \times \mathrm{NPP}_{\text {canopy }}$. Despite the linear trend, we did not find a significant relationship using only our dataset $\left(\mathrm{NPP}_{\text {stem }}=1.63( \pm 0.14) \times \mathrm{NPP}_{\text {canopy }}, n=9\right.$, $p=0.2$ ). The weak relationship observed in our data alone is mainly caused by Colombian site (AGP) with high stem production and relatively low litterfall production. Without this plot, the relationship is similar to the one presented by Malhi et al. (2004), with no significant difference between the slopes $(z$-test $)\left(\mathrm{NPP}_{\text {canopy }}=1.78( \pm 0.11) \times \mathrm{NPP}_{\text {stem }}, n=8\right.$, $\left.R^{2}=0.64, p<0.02\right)$. A significant relationship is also retained $\left(\mathrm{NPP}_{\text {canopy }}=1.67( \pm 0.07) \times \mathrm{NPP}_{\text {stem }}, n=29, R^{2}=0.67\right.$, $p<0.001$ ) when we merge all data together, including this study and Malhi et al. (2004) (Fig. 6).

\subsection{Effect of soil and leaf phosphorus and nitrogen and soil texture on patterns of above- and below-ground NPP in Amazonia}

The observed responses in our study are consistent with the predictions of the hypothesis of soil phosphorus limitation of NPP in Amazonian tropical forests (see also Quesada et al., 2009a). We demonstrated that $\mathrm{NPP}_{\text {total }}$ is significantly correlated to soil available phosphorus $\left(R^{2}=0.54, n=9, p=0.03\right)$ (Fig. 7a). The correlation between these two variables was also significant according to the Spearman rank correlation $(R=0.73, n=9, p=0.03)$ and the Kendall tau (tau=0.54, $n=9$, $p=0.05$ ) (Table 4). On the other hand, we did not find a clear relationship between $\mathrm{NPP}_{\text {total }}$ and soil nitrogen $\left(R^{2}=0.29\right.$, $p=0.13$ ) (Fig. 7b). We also did not find significant relationships between $\mathrm{NPP}_{\text {total }}$ and any other soil and climate variable, except total extractable P (see Quesada et al., 2009c, for method) according to both Spearman $(p=0.01)$ and Kendall tau $(p=0.02)$ (Table 4). These results indicate that soil phosphorus is likely to be more important than nitrogen in the determination of $\mathrm{NPP}_{\text {total }}$ across Amazonia. The slope of 

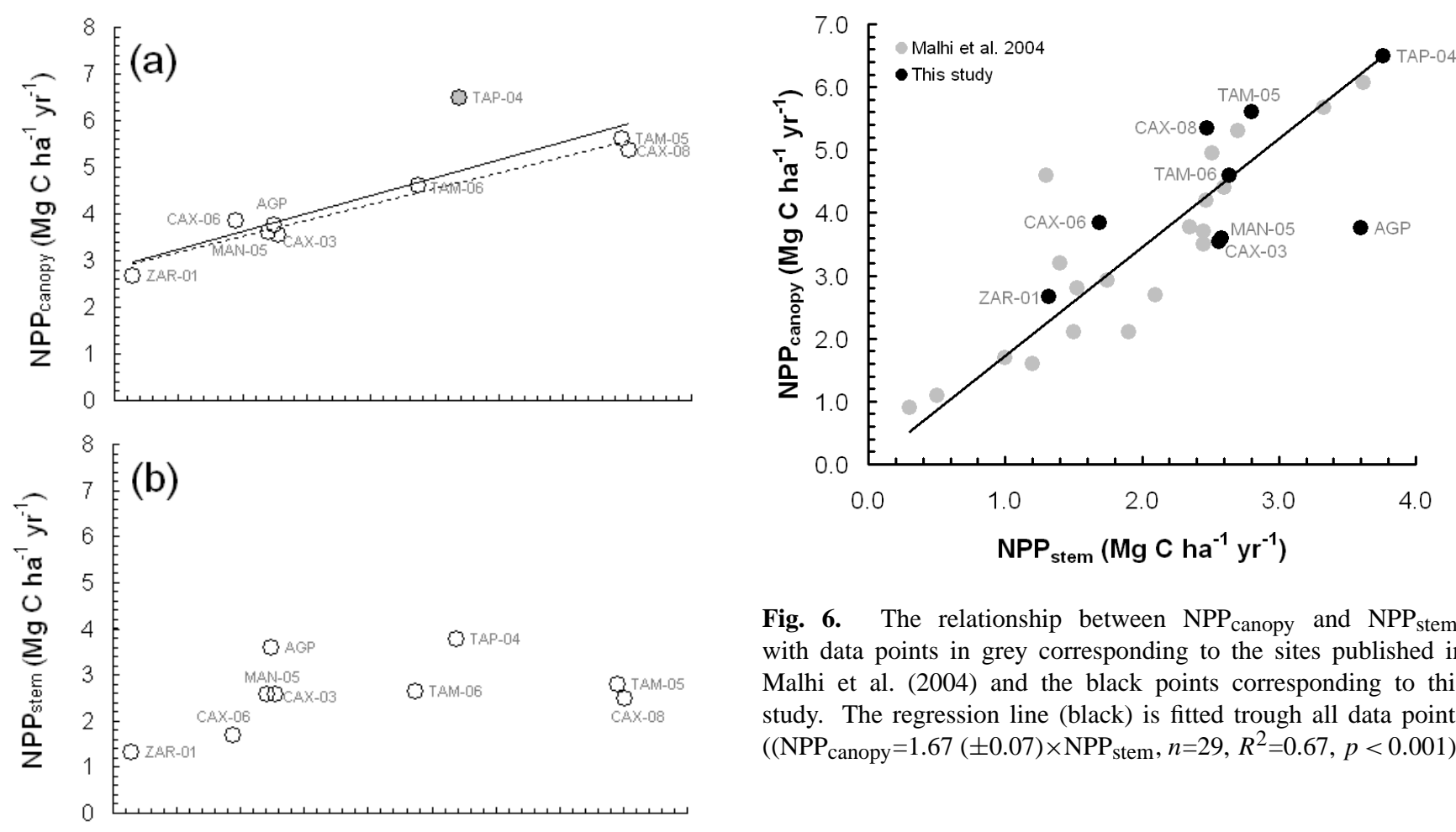

Fig. 6. The relationship between $\mathrm{NPP}_{\text {canopy }}$ and $\mathrm{NPP}_{\text {stem }}$, with data points in grey corresponding to the sites published in Malhi et al. (2004) and the black points corresponding to this study. The regression line (black) is fitted trough all data points $\left(\left(\mathrm{NPP}_{\text {canopy }}=1.67( \pm 0.07) \times \mathrm{NPP}_{\text {stem }}, n=29, R^{2}=0.67, p<0.001\right)\right.$.

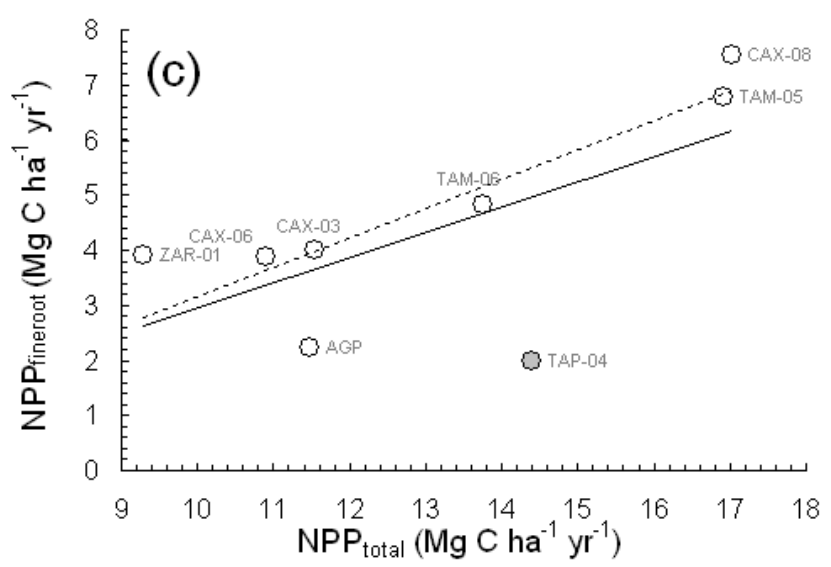

Another noteworthy feature is that $\mathrm{NPP}_{\mathrm{AG}}$ shows no relationship with $\mathrm{P}_{\text {soil }}$ and a weak correlation with total extractable P (Spearman's correlation, $R=0.66, n=9$, $p=0.05$, Table 4), but NPP $\mathrm{BG}_{\mathrm{BG}}$ increases significantly with $\mathrm{P}_{\text {soil }}\left(R^{2}=0.62, n=8, p=0.01\right)$ (Fig. 7a), mainly because of increases in fine root productivity $\left(R^{2}=0.56, n=8, p=0.03\right.$, data not shown). No significant trends were found between above- and below-ground NPP and either soil nitrogen (Fig. 7b, Table 4) or any other soil or climate variable (Table 4). Separating the subcomponents of $\mathrm{NPP}_{\mathrm{AG}}$ there was no increase of $\mathrm{NPP}_{\text {stem }}$ with $\mathrm{P}_{\text {soil }}$. However, with the Tapajós site excluded, the observed increase in $\mathrm{NPP}_{\text {canopy }}$ with $\mathrm{P}_{\text {soil }}$ became significant $\left(R^{2}=0.52, n=8, p<0.04\right)$. In contrast to the clear responses of NPP to soil available phosphorus (Fig. 7a), NPP total appears invariant with changes in leaf phosphorus and nitrogen concentrations (Fig. 7c and d) despite the significance achieved using the Spearman and Kendall tau tests for both variables ( $p<0.05$, Table 4$)$.

Interestingly, the relative proportion of $\mathrm{NPP}_{\text {total }}$ allocated to the below-ground component $\left(\mathrm{NPP}_{\mathrm{BG}} / \mathrm{NPP}_{\text {total }}\right)$ is not affected by either soil or leaf $\mathrm{N}$ and $\mathrm{P}$, but instead changes strongly with soil clay content according to two correlation tests (Kendall's tau $=0.57, p=0.04$, Pearson's $R=0.73$, $p=0.04, n=8$ ) (Table 4). The regression analysis showed below-ground allocation declines with increasing clay content $\left(R^{2}=0.52, n=8, p=0.04\right)$ (Fig. 8 ).

Fine root turnover time tend to increase from the more the regression did not change significantly ( $z$-test) when removing the Tapajós or the Terra Preta site, possibly because the effect of $\mathrm{P}_{\text {soil }}$ on NPP is independent of disturbance history. fertile to the less fertile sites as $0.97 \mathrm{yr}^{-1}(\mathrm{CAX}-08)<$ $1.04 \mathrm{yr}^{-1}(\mathrm{TAM}-06)<1.14 \mathrm{yr}^{-1}(\mathrm{TAM}-05)<1.21 \mathrm{yr}^{-1}$ $($ AGP $)<1.55 \mathrm{yr}^{-1}\left(\right.$ TAP-04) $<2.12 \mathrm{yr}^{-1}(\mathrm{ZAR}-01)<$ $2.27 \mathrm{yr}^{-1}(\mathrm{CAX}-03)<2.50 \mathrm{yr}^{-1}(\mathrm{CAX}-06)$. These values 

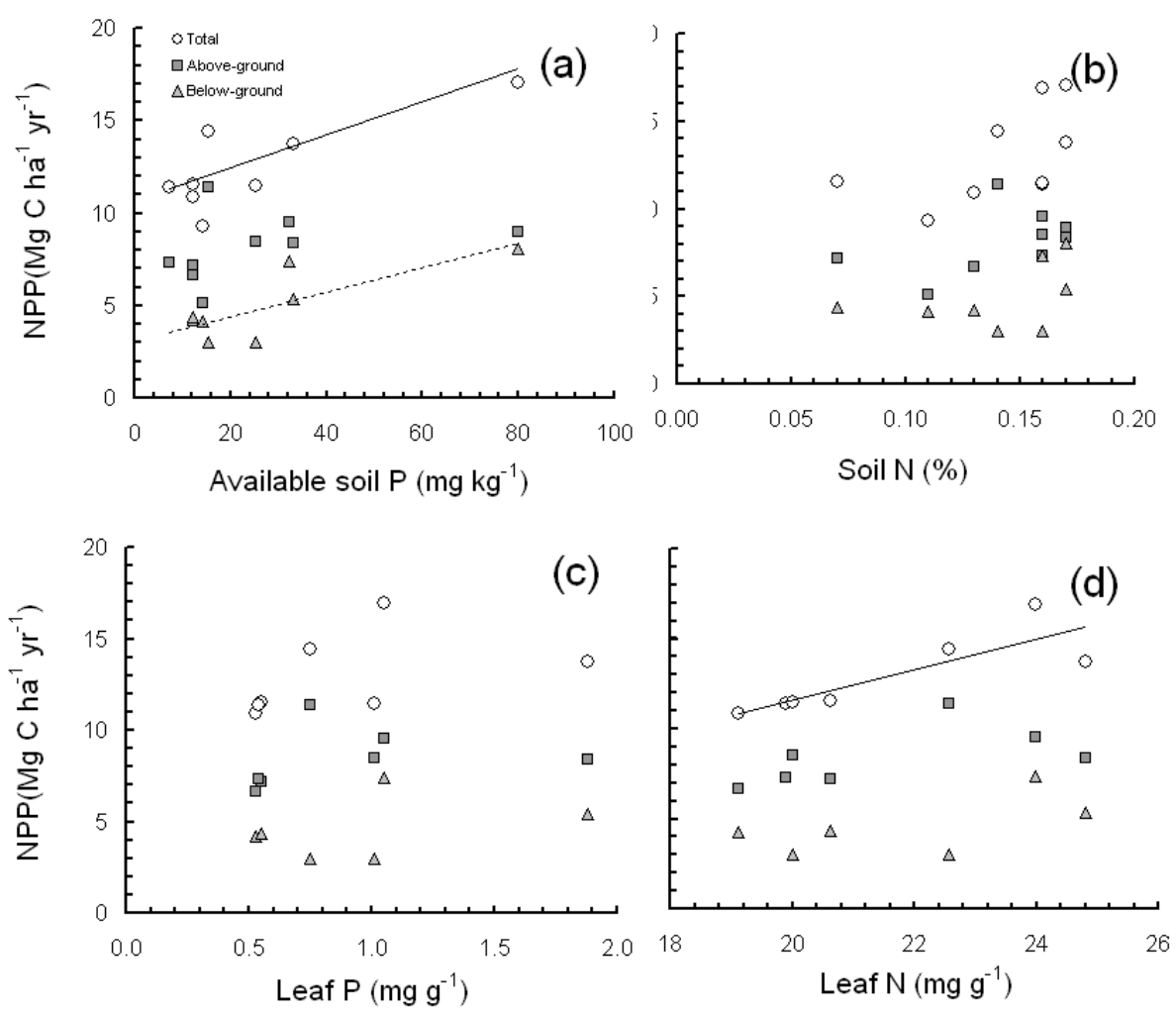

Fig. 7. (a) The relationship between $\mathrm{NPP}_{\text {total }}$ (open circles) and its above- (dark grey squares) and below-ground (light grey triangles) components and soil available phosphorus $\left(\mathrm{P}_{\text {available }}\right)$. The linear regression equation for the significant relationship between $\mathrm{NPP}_{\text {total }}$ and $\mathrm{P}_{\text {available }}$ (black line) is: $\mathrm{NPP}_{\text {total }}=0.09( \pm 0.03) \times \mathrm{P}_{\text {available }}+10.66( \pm 1.04)\left(R^{2}=0.54, n=9, p=0.03\right)$, and $\mathrm{NPP}_{\mathrm{BG}}$ and $\mathrm{P}_{\mathrm{available}}$ is: $\mathrm{NPP}_{\mathrm{BG}}=0.07( \pm 0.02) \times \mathrm{P}_{\text {available }}+3.10( \pm 0.74)\left(R^{2}=0.62, n=8, p=0.02\right)$. (b) The relationship between $\mathrm{NPP}_{\text {total }}$ (open circles $)$ and its above(dark grey squares) and below-ground (light grey triangles) components and soil nitrogen concentration $\left(\mathrm{N}_{\text {soil }}\right)$. (c) The relationship between $\mathrm{NPP}_{\text {total }}$ (open circles) and its above- (dark grey squares) and below-ground (light grey triangles) components and leaf phosphorus concentration $\left(\mathrm{P}_{\text {leaf }}\right)$. (d) The relationship between $\mathrm{NPP}_{\text {total }}$ (open circles) and its above- (dark grey squares) and below-ground (light grey triangles) components and leaf nitrogen concentration $\left(\mathrm{N}_{\text {leaf }}\right)$. The relationships for $(\mathrm{a})$, (b) and (c) were no significant for all variables analysed.

are best related with log transformed $\mathrm{P}_{\text {soil }}\left(R^{2}=0.74, n=8\right.$, $p=0.006$ ), however other soil attributes such as $\mathrm{N}$, cation exchange capacity (CEC) and total extractable $P$ are also significantly correlated with root turnover (Table 4). The relationship between $\mathrm{P}_{\text {soil }}$ and root turnover is non-linear and follows a power function (Fig. 9).

\section{Discussion}

The $\mathrm{NPP}_{\mathrm{AG}}$ and $\mathrm{NPP}_{\mathrm{BG}}$ values presented in this study for Amazonia are within the range of values reported for other tropical forests (Clark et al., 2001a). However, the average $\mathrm{NPP}_{\text {total }}$ for the ten sites analysed here $\left(12.8 \pm 0.9 \mathrm{MgCha}^{-1} \mathrm{yr}^{-1}\right)$ is significantly greater than the value reported by Luyssaert et al. (2007) $\left(8.64 \pm 0.2 \mathrm{Mg} \mathrm{Cha}^{-1} \mathrm{yr}^{-1}\right)$ for 29 tropical humid evergreen forests across the globe which conspicuously lacked Amazon data ( $z$-test, $p<0.001$ ).
The $\mathrm{NPP}_{\text {canopy }}$ for most of the sites analysed here falls near the average value of 51 old growth-forest plots in Amazonia, 4.3 $\pm 0.9 \mathrm{Mg} \mathrm{Cha}^{-1} \mathrm{yr}^{-1}$ (Chave et al., 2009). Canopy productivity ( $\left.\mathrm{NPP}_{\text {canopy }}\right)$ is likely to be underestimated when estimated from litterfall measurements. This problem arises because part of the produced material can decompose or be consumed by herbivores before hitting the ground (Clark et al., 2001b). Corrections can be applied to adjust these effects (Keeling and Phillips, 2007). However, here we did not attempt to correct our values as the rates of decomposition and herbivory may increase from the driest to the wettest sites, and may increase with soil fertility, which would introduce uncertainties that cannot be accounted for in our analysis. We expect that the underestimation of canopy productivity may be larger at AGP-01 and AGP-02, due to the higher rainfall and lack of dry season in comparison to the other sites. Another source of uncertainty is the production of palm litter, especially at TAM-06, that was not accounted for in this study but which would increase our litterfall estimations for this site, and to a lesser degree at AGP-01 and AGP-02. 
Table 4. Spearman's rank correlation, Kendall's tau and Pearson's product-moment correlation between total NPP, its above- and belowground components and the environmental variables. Bold values are significant at $95 \%$ confidence interval and negative values indicate an inverse correlation.

\begin{tabular}{|c|c|c|c|c|c|c|c|c|c|c|c|}
\hline \multirow[b]{2}{*}{ Dependent } & \multirow{2}{*}{$\begin{array}{l}\text { Variables } \\
\text { Independent }\end{array}$} & \multirow[b]{2}{*}{$n$} & \multicolumn{3}{|c|}{ Spearman rank } & \multicolumn{3}{|c|}{ Kendall tau } & \multicolumn{3}{|c|}{ Pearson product-moment } \\
\hline & & & $r$ & $t$ & $p$ & Tau & $Z$ & $p$ & $r^{2}$ & $t$ & $p$ \\
\hline $\mathrm{NPP}_{\mathrm{AG}}$ & $\mathrm{P}_{\text {soil }}$ & 9 & 0.59 & 1.95 & 0.09 & 0.31 & 1.16 & 0.24 & 0.32 & 0.90 & 0.40 \\
\hline $\mathrm{NPP}_{\mathrm{AG}}$ & $\mathrm{N}_{\text {soil }}$ & 9 & 0.54 & 1.72 & 0.13 & 0.35 & 1.33 & 0.18 & 0.46 & 1.36 & 0.22 \\
\hline $\mathrm{NPP}_{\mathrm{AG}}$ & $\mathrm{P}_{\text {leaf }}$ & 7 & 0.64 & 1.88 & 0.12 & 0.43 & 1.35 & 0.18 & 0.24 & 0.56 & 0.60 \\
\hline $\mathrm{NPP}_{\mathrm{AG}}$ & $\mathrm{N}_{\text {leaf }}$ & 7 & 0.61 & 1.71 & 0.15 & 0.43 & 1.35 & 0.18 & 0.59 & 1.63 & 0.16 \\
\hline $\mathrm{NPP}_{\mathrm{AG}}$ & Clay & 9 & 0.28 & 0.78 & 0.46 & 0.17 & 0.63 & 0.53 & 0.50 & 1.54 & 0.17 \\
\hline $\mathrm{NPP}_{\mathrm{AG}}$ & CEC & 9 & 0.63 & 2.17 & 0.07 & 0.50 & 1.88 & 0.06 & 0.35 & 1.00 & 0.35 \\
\hline $\mathrm{NPP}_{\mathrm{AG}}$ & Sum of the bases & 8 & 0.00 & 0.00 & 1.00 & 0.00 & 0.00 & 1.00 & 0.14 & 0.34 & 0.74 \\
\hline $\mathrm{NPP}_{\mathrm{AG}}$ & $\%$ Base saturation & 8 & -0.33 & -0.87 & 0.42 & -0.29 & -0.99 & 0.32 & 0.44 & -1.21 & 0.27 \\
\hline $\mathrm{NPP}_{\mathrm{AG}}$ & $\mathrm{Ca}_{\text {soil }}$ & 9 & 0.07 & 0.18 & 0.86 & 0.00 & 0.00 & 1.00 & 0.19 & 0.52 & 0.62 \\
\hline $\mathrm{NPP}_{\mathrm{AG}}$ & $\mathrm{K}_{\text {soil }}$ & 8 & -0.11 & -0.27 & 0.80 & -0.11 & -0.38 & 0.71 & 0.31 & -0.80 & 0.45 \\
\hline $\mathrm{NPP}_{\mathrm{AG}}$ & $\mathrm{Mg}_{\text {soil }}$ & 8 & 0.05 & 0.12 & 0.91 & 0.00 & 0.00 & 1.00 & 0.12 & 0.30 & 0.77 \\
\hline $\mathrm{NPP}_{\mathrm{AG}}$ & $\mathrm{P}_{\text {extractable }}$ & 9 & 0.66 & 2.33 & 0.05 & 0.42 & 1.59 & 0.11 & 0.33 & 0.93 & 0.38 \\
\hline $\mathrm{NPP}_{\mathrm{AG}}$ & $\mathrm{Na}_{\text {soil }}$ & 8 & -0.48 & -1.35 & 0.23 & -0.37 & -1.28 & 0.20 & 0.39 & -1.05 & 0.33 \\
\hline $\mathrm{NPP}_{\mathrm{AG}}$ & $\mathrm{Al}_{\text {soil }}$ & 7 & 0.61 & 1.71 & 0.15 & 0.43 & 1.35 & 0.18 & 0.43 & 1.07 & 0.33 \\
\hline $\mathrm{NPP}_{\mathrm{AG}}$ & $\mathrm{N}_{\text {leaf unit area }}$ & 9 & 0.57 & 1.83 & 0.11 & 0.48 & 1.80 & 0.07 & 0.46 & 1.35 & 0.22 \\
\hline $\mathrm{NPP}_{\mathrm{AG}}$ & $\mathrm{P}_{\text {leaf unit area }}$ & 9 & 0.50 & 1.54 & 0.17 & 0.42 & 1.59 & 0.11 & 0.39 & 1.12 & 0.30 \\
\hline $\mathrm{NPP}_{\mathrm{AG}}$ & Rainfall & 9 & -0.27 & -0.75 & 0.48 & -0.21 & -0.79 & 0.43 & 0.59 & -1.95 & 0.09 \\
\hline $\mathrm{NPP}_{\mathrm{AG}}$ & Temperature & 9 & -0.27 & -0.75 & 0.48 & -0.15 & -0.56 & 0.57 & 0.16 & -0.42 & 0.69 \\
\hline $\mathrm{NPP}_{A G}$ & DSL & 9 & 0.36 & 1.02 & 0.34 & 0.27 & 1.01 & 0.31 & 0.49 & 1.48 & 0.18 \\
\hline $\mathrm{NPP}_{\mathrm{BG}}$ & $\mathrm{P}_{\text {soil }}$ & 8 & 0.51 & 1.47 & 0.19 & 0.25 & 0.88 & 0.38 & 0.79 & 3.14 & 0.02 \\
\hline $\mathrm{NPP}_{\mathrm{BG}}$ & $\mathrm{N}_{\text {soil }}$ & 8 & 0.43 & 1.18 & 0.28 & 0.22 & 0.77 & 0.44 & 0.41 & 1.10 & 0.31 \\
\hline $\mathrm{NPP}_{\mathrm{BG}}$ & $\mathrm{P}_{\text {leaf }}$ & 6 & 0.43 & 0.95 & 0.40 & 0.20 & 0.56 & 0.57 & 0.36 & 0.77 & 0.48 \\
\hline $\mathrm{NPP}_{\mathrm{BG}}$ & $\mathrm{N}_{\text {leaf }}$ & 6 & 0.66 & 1.74 & 0.16 & 0.47 & 1.32 & 0.19 & 0.60 & 1.51 & 0.21 \\
\hline $\mathrm{NPP}_{\mathrm{BG}}$ & Clay & 8 & -0.40 & -1.08 & 0.32 & -0.29 & -0.99 & 0.32 & 0.39 & -1.03 & 0.34 \\
\hline $\mathrm{NPP}_{\mathrm{BG}}$ & CEC & 8 & 0.31 & 0.80 & 0.46 & 0.21 & 0.74 & 0.46 & 0.66 & 2.15 & 0.07 \\
\hline $\mathrm{NPP}_{\mathrm{BG}}$ & Sum of the bases & 7 & 0.14 & 0.32 & 0.76 & 0.05 & 0.15 & 0.88 & 0.54 & 1.45 & 0.21 \\
\hline $\mathrm{NPP}_{\mathrm{BG}}$ & $\%$ Base saturation & 7 & 0.07 & 0.16 & 0.88 & 0.05 & 0.15 & 0.88 & 0.03 & -0.06 & 0.96 \\
\hline $\mathrm{NPP}_{\mathrm{BG}}$ & $\mathrm{Ca}_{\text {soil }}$ & 8 & 0.05 & 0.12 & 0.91 & -0.07 & -0.25 & 0.80 & 0.60 & 1.82 & 0.12 \\
\hline $\mathrm{NPP}_{\mathrm{BG}}$ & $\mathrm{K}_{\text {soil }}$ & 7 & -0.04 & -0.08 & 0.94 & -0.05 & -0.15 & 0.88 & 0.08 & -0.19 & 0.86 \\
\hline $\mathrm{NPP}_{\mathrm{BG}}$ & $\mathrm{Mg}_{\text {soil }}$ & 7 & 0.07 & 0.16 & 0.88 & -0.05 & -0.15 & 0.88 & 0.44 & 1.08 & 0.33 \\
\hline $\mathrm{NPP}_{\mathrm{BG}}$ & $\mathrm{P}_{\text {extractable }}$ & 8 & 0.44 & 1.21 & 0.27 & 0.33 & 1.13 & 0.26 & 0.60 & 1.84 & 0.12 \\
\hline $\mathrm{NPP}_{\mathrm{BG}}$ & $\mathrm{Na}_{\text {soil }}$ & 7 & 0.23 & 0.54 & 0.61 & 0.20 & 0.62 & 0.54 & 0.06 & 0.13 & 0.90 \\
\hline $\mathrm{NPP}_{\mathrm{BG}}$ & $\mathrm{Al}_{\text {soil }}$ & 6 & -0.26 & -0.53 & 0.62 & -0.20 & -0.56 & 0.57 & 0.06 & 0.12 & 0.91 \\
\hline $\mathrm{NPP}_{\mathrm{BG}}$ & $\mathrm{N}_{\text {leaf unit area }}$ & 8 & 0.04 & 0.09 & 0.93 & 0.11 & 0.38 & 0.71 & 0.28 & -0.71 & 0.50 \\
\hline $\mathrm{NPP}_{\mathrm{BG}}$ & $\mathrm{P}_{\text {leaf unit area }}$ & 8 & -0.01 & -0.03 & 0.98 & -0.04 & -0.13 & 0.90 & 0.09 & -0.21 & 0.84 \\
\hline $\mathrm{NPP}_{\mathrm{BG}}$ & Rainfall & 8 & -0.19 & -0.46 & 0.66 & -0.12 & -0.41 & 0.68 & 0.04 & -0.11 & 0.92 \\
\hline $\mathrm{NPP}_{\mathrm{BG}}$ & Temperature & 8 & 0.01 & 0.03 & 0.98 & 0.04 & 0.14 & 0.89 & 0.04 & 0.10 & 0.92 \\
\hline $\mathrm{NPP}_{\mathrm{BG}}$ & DSL & 8 & 0.19 & 0.46 & 0.66 & 0.12 & 0.41 & 0.68 & 0.34 & 0.90 & 0.41 \\
\hline $\mathrm{NPP}_{\text {total }}$ & $\mathrm{P}_{\text {soil }}$ & 9 & 0.73 & 2.81 & 0.03 & 0.54 & 2.01 & 0.04 & 0.73 & 2.85 & 0.02 \\
\hline $\mathrm{NPP}_{\text {total }}$ & $\mathrm{N}_{\text {soil }}$ & 9 & 0.57 & 1.84 & 0.11 & 0.47 & 1.77 & 0.08 & 0.54 & 1.71 & 0.13 \\
\hline $\mathrm{NPP}_{\text {total }}$ & $\mathrm{P}_{\text {leaf }}$ & 7 & 0.75 & 2.54 & 0.05 & 0.62 & 1.95 & 0.05 & 0.44 & 1.09 & 0.32 \\
\hline $\mathrm{NPP}_{\text {total }}$ & $\mathrm{N}_{\text {leaf }}$ & 7 & 0.89 & 4.43 & 0.01 & 0.81 & 2.55 & 0.01 & 0.85 & 3.59 & 0.02 \\
\hline $\mathrm{NPP}_{\text {total }}$ & Clay & 9 & 0.00 & 0.00 & 1.00 & -0.06 & -0.21 & 0.83 & 0.06 & 0.17 & 0.87 \\
\hline $\mathrm{NPP}_{\text {total }}$ & CEC & 9 & 0.63 & 2.17 & 0.07 & 0.50 & 1.88 & 0.06 & 0.67 & 2.41 & 0.05 \\
\hline $\mathrm{NPP}_{\text {total }}$ & Sum of the bases & 8 & 0.21 & 0.54 & 0.61 & 0.14 & 0.49 & 0.62 & 0.47 & 1.29 & 0.24 \\
\hline $\mathrm{NPP}_{\text {total }}$ & $\%$ Base saturation & 8 & -0.19 & -0.48 & 0.65 & -0.14 & -0.49 & 0.62 & 0.28 & -0.70 & 0.51 \\
\hline $\mathrm{NPP}_{\text {total }}$ & $\mathrm{Ca}_{\text {soil }}$ & 9 & 0.17 & 0.45 & 0.67 & 0.11 & 0.42 & 0.68 & 0.53 & 1.65 & 0.14 \\
\hline $\mathrm{NPP}_{\text {total }}$ & $\mathrm{K}_{\text {soil }}$ & 8 & 0.01 & 0.03 & 0.98 & 0.04 & 0.13 & 0.90 & 0.22 & -0.55 & 0.60 \\
\hline $\mathrm{NPP}_{\text {total }}$ & $\mathrm{Mg}_{\text {soil }}$ & 8 & 0.24 & 0.60 & 0.57 & 0.14 & 0.49 & 0.62 & 0.39 & 1.03 & 0.34 \\
\hline $\mathrm{NPP}_{\text {total }}$ & $\mathrm{P}_{\text {extractable }}$ & 9 & 0.78 & 3.28 & 0.01 & 0.65 & 2.43 & 0.02 & 0.62 & 2.11 & 0.07 \\
\hline $\mathrm{NPP}_{\text {total }}$ & $\mathrm{Na}_{\text {soil }}$ & 8 & -0.30 & -0.77 & 0.47 & -0.22 & -0.77 & 0.44 & 0.24 & -0.61 & 0.56 \\
\hline
\end{tabular}


Table 4. Continued.

\begin{tabular}{|c|c|c|c|c|c|c|c|c|c|c|c|}
\hline \multicolumn{3}{|c|}{ Variables } & \multicolumn{3}{|c|}{ Spearman rank } & \multicolumn{3}{|c|}{ Kendall tau } & \multicolumn{3}{|c|}{ Pearson product-moment } \\
\hline Dependent & Independent & $n$ & $r$ & $t$ & $p$ & Tau & Z & $p$ & $r^{2}$ & $t$ & $p$ \\
\hline $\mathrm{NPP}_{\text {total }}$ & $\mathrm{Al}_{\text {soil }}$ & 7 & 0.50 & 1.29 & 0.25 & 0.43 & 1.35 & 0.18 & 0.37 & 0.90 & 0.41 \\
\hline $\mathrm{NPP}_{\text {total }}$ & $\mathrm{N}_{\text {leaf unit area }}$ & 9 & 0.38 & 1.10 & 0.31 & 0.37 & 1.37 & 0.17 & 0.11 & 0.29 & 0.78 \\
\hline $\mathrm{NPP}_{\text {total }}$ & $\mathrm{P}_{\text {leaf unit area }}$ & 9 & 0.32 & 0.89 & 0.40 & 0.31 & 1.16 & 0.24 & 0.21 & 0.58 & 0.58 \\
\hline $\mathrm{NPP}_{\text {total }}$ & Rainfall & 9 & -0.25 & -0.68 & 0.52 & -0.21 & -0.79 & 0.43 & 0.41 & -1.17 & 0.28 \\
\hline $\mathrm{NPP}_{\text {total }}$ & Temperature & 9 & -0.21 & -0.58 & 0.58 & -0.15 & -0.56 & 0.57 & 0.13 & -0.34 & 0.75 \\
\hline $\mathrm{NPP}_{\text {total }}$ & DSL & 9 & 0.50 & 1.55 & 0.17 & 0.39 & 1.46 & 0.14 & 0.55 & 1.73 & 0.13 \\
\hline $\mathrm{NPP}_{\mathrm{BG}} / \mathrm{NPP}_{\text {total }}$ & $\mathrm{P}_{\text {soil }}$ & 8 & 0.44 & 1.21 & 0.27 & 0.33 & 1.13 & 0.26 & 0.20 & 0.45 & 0.26 \\
\hline $\mathrm{NPP}_{\mathrm{BG}} / \mathrm{NPP}_{\text {total }}$ & $\mathrm{N}_{\text {soil }}$ & 8 & 0.30 & 0.77 & 0.47 & 0.22 & 0.77 & 0.44 & 0.00 & 0.01 & 0.99 \\
\hline $\mathrm{NPP}_{\mathrm{BG}} / \mathrm{NPP}_{\text {total }}$ & $\mathrm{P}_{\text {leaf }}$ & 6 & 0.43 & 0.95 & 0.40 & 0.20 & 0.56 & 0.57 & 0.04 & 0.20 & 0.71 \\
\hline $\mathrm{NPP}_{\mathrm{BG}} / \mathrm{NPP}_{\text {total }}$ & $\mathrm{N}_{\text {leaf }}$ & 6 & 0.43 & 0.95 & 0.40 & 0.20 & 0.56 & 0.57 & 0.05 & 0.23 & 0.66 \\
\hline $\mathrm{NPP}_{\mathrm{BG}} / \mathrm{NPP}_{\text {total }}$ & Clay & 8 & -0.67 & -2.19 & 0.07 & -0.57 & -1.98 & 0.05 & 0.53 & 0.72 & 0.04 \\
\hline $\mathrm{NPP}_{\mathrm{BG}} / \mathrm{NPP}_{\text {total }}$ & CEC & 8 & 0.12 & 0.29 & 0.78 & 0.07 & 0.25 & 0.80 & 0.09 & 0.29 & 0.48 \\
\hline $\mathrm{NPP}_{\mathrm{BG}} / \mathrm{NPP}_{\text {total }}$ & Sum of the bases & 7 & 0.32 & 0.76 & 0.48 & 0.24 & 0.75 & 0.45 & 0.15 & 0.38 & 0.40 \\
\hline $\mathrm{NPP}_{\mathrm{BG}} / \mathrm{NPP}_{\text {total }}$ & $\%$ Base saturation & 7 & 0.39 & 0.96 & 0.38 & 0.24 & 0.75 & 0.45 & 0.13 & 0.37 & 0.42 \\
\hline $\mathrm{NPP}_{\mathrm{BG}} / \mathrm{NPP}_{\text {total }}$ & $\mathrm{Ca}_{\text {soil }}$ & 8 & 0.29 & 0.73 & 0.49 & 0.21 & 0.74 & 0.46 & 0.15 & 0.38 & 0.35 \\
\hline $\mathrm{NPP}_{\mathrm{BG}} / \mathrm{NPP}_{\text {total }}$ & $\mathrm{K}_{\text {soil }}$ & 7 & 0.29 & 0.67 & 0.53 & 0.14 & 0.45 & 0.65 & 0.04 & 0.19 & 0.69 \\
\hline $\mathrm{NPP}_{\mathrm{BG}} / \mathrm{NPP}_{\text {total }}$ & $\mathrm{Mg}_{\text {soil }}$ & 7 & 0.21 & 0.49 & 0.64 & 0.14 & 0.45 & 0.65 & 0.10 & 0.31 & 0.50 \\
\hline $\mathrm{NPP}_{\mathrm{BG}} / \mathrm{NPP}_{\text {total }}$ & $\mathrm{P}_{\text {extractable }}$ & 8 & 0.18 & 0.45 & 0.67 & 0.11 & 0.38 & 0.71 & 0.08 & 0.28 & 0.51 \\
\hline $\mathrm{NPP}_{\mathrm{BG}} / \mathrm{NPP}_{\text {total }}$ & $\mathrm{Na}_{\text {soil }}$ & 7 & 0.27 & 0.63 & 0.56 & 0.20 & 0.62 & 0.54 & 0.09 & 0.30 & 0.51 \\
\hline $\mathrm{NPP}_{\mathrm{BG}} / \mathrm{NPP}_{\text {total }}$ & $\mathrm{Al}_{\text {soil }}$ & 6 & -0.54 & -1.29 & 0.27 & -0.47 & -1.32 & 0.19 & 0.14 & 0.37 & 0.47 \\
\hline $\mathrm{NPP}_{\mathrm{BG}} / \mathrm{NPP}_{\text {total }}$ & $\mathrm{N}_{\text {leaf unit area }}$ & 8 & -0.40 & -1.05 & 0.33 & -0.33 & -1.13 & 0.26 & 0.31 & 0.56 & 0.15 \\
\hline $\mathrm{NPP}_{\mathrm{BG}} / \mathrm{NPP}_{\text {total }}$ & $\mathrm{P}_{\text {leaf unit area }}$ & 8 & -0.40 & -1.05 & 0.33 & -0.33 & -1.13 & 0.26 & 0.11 & 0.33 & 0.43 \\
\hline $\mathrm{NPP}_{\mathrm{BG}} / \mathrm{NPP}_{\text {total }}$ & Rainfall & 8 & 0.30 & 0.76 & 0.48 & 0.28 & 0.96 & 0.34 & 0.10 & 0.32 & 0.44 \\
\hline $\mathrm{NPP}_{\mathrm{BG}} / \mathrm{NPP}_{\text {total }}$ & Temperature & 8 & -0.10 & -0.24 & 0.82 & -0.04 & -0.14 & 0.89 & 0.01 & 0.07 & 0.86 \\
\hline $\mathrm{NPP}_{\mathrm{BG}} / \mathrm{NPP}_{\text {total }}$ & DSL & 8 & -0.30 & -0.76 & 0.48 & -0.28 & -0.96 & 0.34 & 0.00 & 0.01 & 0.98 \\
\hline Root $_{\text {turnover }}$ & $\mathrm{P}_{\text {soil }}$ & 8 & -0.99 & -22.32 & 0.00 & -0.98 & -3.40 & 0.00 & 0.70 & -2.41 & 0.05 \\
\hline Root turnover & $\mathrm{N}_{\text {soil }}$ & 8 & -0.92 & $-\mathbf{5 . 5 8}$ & 0.00 & -0.82 & -2.82 & 0.00 & 0.84 & -3.74 & 0.01 \\
\hline Rootturnover & $\mathrm{P}_{\text {leaf }}$ & 6 & -1.00 & - & - & -1.00 & -2.82 & 0.00 & 0.79 & -2.56 & 0.06 \\
\hline Root turnover & $\mathrm{N}_{\text {leaf }}$ & 6 & $-\mathbf{0 . 8 3}$ & -2.96 & 0.04 & -0.73 & -2.07 & 0.04 & 0.74 & -2.17 & 0.10 \\
\hline Root turnover & Clay & 8 & 0.21 & 0.54 & 0.61 & 0.14 & 0.49 & 0.62 & 0.02 & -0.04 & 0.97 \\
\hline Root turnover & CEC & 8 & -0.83 & -3.69 & 0.01 & -0.64 & -2.23 & $\mathbf{0 . 0 3}$ & 0.71 & -2.50 & 0.05 \\
\hline Rootturnover & Sum of the bases & 7 & -0.61 & -1.71 & 0.15 & -0.52 & -1.65 & 0.10 & 0.59 & -1.63 & 0.16 \\
\hline Root $_{\text {turnover }}$ & $\%$ Base saturation & 7 & -0.04 & -0.08 & 0.94 & 0.05 & 0.15 & 0.88 & 0.06 & 0.13 & 0.90 \\
\hline Root $_{\text {turnover }}$ & $\mathrm{Ca}_{\text {soil }}$ & 8 & -0.60 & -1.81 & 0.12 & -0.50 & -1.73 & 0.08 & 0.62 & -1.94 & 0.10 \\
\hline Root $_{\text {turnover }}$ & $\mathrm{K}_{\text {soil }}$ & 7 & -0.36 & -0.85 & 0.43 & -0.24 & -0.75 & 0.45 & 0.25 & -0.57 & 0.59 \\
\hline Root $_{\text {turnover }}$ & $\mathrm{Mg}_{\text {soil }}$ & 7 & -0.57 & -1.56 & 0.18 & -0.43 & -1.35 & 0.18 & 0.57 & -1.55 & 0.18 \\
\hline Root $_{\text {turnover }}$ & $\mathrm{P}_{\text {extractable }}$ & 8 & -0.90 & -5.01 & 0.00 & -0.76 & -2.65 & 0.01 & 0.78 & -3.08 & 0.02 \\
\hline Root $_{\text {turnover }}$ & $\mathrm{Na}_{\text {soil }}$ & 7 & 0.34 & 0.81 & 0.45 & 0.29 & 0.92 & 0.36 & 0.63 & 1.82 & 0.13 \\
\hline Root $_{\text {turnover }}$ & $\mathrm{Al}_{\text {soil }}$ & 6 & -0.26 & -0.53 & 0.62 & -0.20 & -0.56 & 0.57 & 0.44 & -0.99 & 0.38 \\
\hline Root $_{\text {turnover }}$ & $\mathrm{N}_{\text {leaf unit area }}$ & 8 & -0.28 & -0.70 & 0.51 & -0.25 & -0.88 & 0.38 & 0.12 & -0.31 & 0.77 \\
\hline Root $_{\text {turnover }}$ & $\mathrm{P}_{\text {leaf unit area }}$ & 8 & -0.32 & -0.84 & 0.43 & -0.40 & -1.39 & 0.17 & 0.45 & -1.25 & 0.26 \\
\hline Root $_{\text {turnover }}$ & Rainfall & 8 & -0.16 & -0.40 & 0.70 & -0.04 & -0.14 & 0.89 & 0.03 & -0.08 & 0.94 \\
\hline Root $_{\text {turnover }}$ & Temperature & 8 & 0.43 & 1.17 & 0.28 & 0.43 & 1.50 & 0.13 & 0.48 & 1.34 & 0.23 \\
\hline Root $_{\text {turnover }}$ & DSL & 8 & 0.16 & 0.40 & 0.70 & 0.04 & 0.14 & 0.89 & 0.00 & -0.01 & 0.99 \\
\hline
\end{tabular}

The NPPAG for the TAP-04 site is the second highest among all tropical sites evaluated by Clark et al. (2001a). This site also has the highest value of $\mathrm{NPP}_{\text {canopy }}$ when compared with other old-growth Amazonian forests (Chave et al., 2009). Pyle et al. (2008) and Malhi et al. (2009) suggested that the Tapajós forest is in disequilibrium as a consequence of large scale natural disturbance in this area in the 1990s. The increase of canopy opening, as a consequence of disturbance, is likely to increase competition for light, favour species and individuals with disproportionate stem allocation and new leaf production, and thus lead to increased above-ground allocation. Therefore, this site should be interpreted with caution in our analysis of old-growth Amazonian forests. 

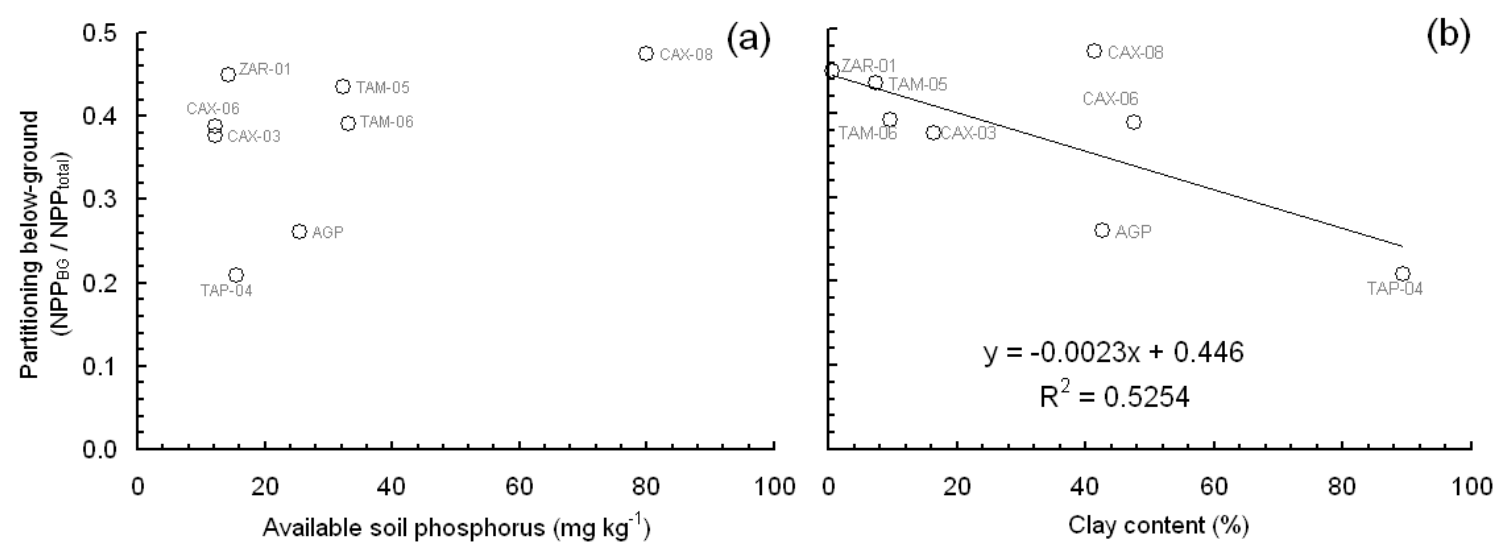

Fig. 8. The relationship between the proportion of $\mathrm{NPP}_{\text {total }}$ allocated below-ground $\left(\mathrm{NPP}_{\mathrm{BG}} / \mathrm{NPP}_{\text {total }}\right)$ and (a) available soil phosphorus concentration and (b) soil clay content. The regression line in black indicates a significant relationship $\left(\left(\mathrm{NPP}_{\mathrm{BG}} / \mathrm{NPP}_{\text {total }}\right)=-0.0022( \pm 0.001) \times\right.$ Clay+0.45 $\left.( \pm 0.04), R^{2}=0.53, n=8, p=0.04\right)$.

\subsection{How do $\mathrm{NPP}_{\mathrm{AG}}$ and $\mathrm{NPP}_{\mathrm{BG}}$ and their subcompo- nents vary with $\mathbf{N P P}_{\text {total }}$ ?}

Both $\mathrm{NPP}_{\mathrm{AG}}$ and $\mathrm{NPP}_{\mathrm{BG}}$ increase with the increase of $\mathrm{NPP}_{\text {total }}$. This pattern follows the hypothesis proposed by Nadelhoffer et al. (1985) where fine root production increases in direct proportion to increases in above-ground production. The mechanisms causing the overall increase of $\mathrm{NPP}_{\text {total }}$ were not evaluated. $\mathrm{NPP}_{\text {total }}$ can be expressed as the total amount of $\mathrm{C}$ entering the system through gross primary productivity (GPP) or photosynthesis multiplied by the carbon use efficiency (CUE=NPP/GPP). Hence, higher NPP sites must have either higher GPP, greater CUE (i.e. less autotrophic respiration), or both.

Our results also indicated that $\mathrm{NPP}_{\text {canopy }}$ and $\mathrm{NPP}_{\text {fineroot }}$ increase with $\mathrm{NPP}_{\text {total}}$, while $\mathrm{NPP}_{\text {stem }}$ shows less variation. Hence $\mathrm{NPP}_{\text {stem }}$ appears to be a weak predictor of $\mathrm{NPP}_{\text {total }}$. On the other hand, the strong empirical relation found between $\mathrm{NPP}_{\text {total }}$ and $\mathrm{NPP}_{\text {canopy }}$ points towards $\mathrm{NPP}_{\text {canopy }}$ as perhaps being the most suitable simple predictor of $\mathrm{NPP}_{\text {total }}$ of Amazonian undisturbed terra firme forests. Even if litterfall production is systematically underestimated by field measurements (Clark et al., 2001b) the use of a multiplier, such as 1.613 as proposed by Keeling and Phillips (2007), assuming that decomposition of the material trapped in the trees results in a $38 \%$ reduction in the litterfall mass that hits the ground, would not affect the shape of the relationship presented here. However, the slope and intercept of the regression would change in the same proportion. The increase of $\mathrm{NPP}_{\text {canopy }}$ and $\mathrm{NPP}_{\text {fineroot }}$ with $\mathrm{NPP}_{\text {total }}$ indicates invariance in the ratio of $\mathrm{NPP}_{\text {canopy }}$ and $\mathrm{NPP}_{\text {fineroot. In general, }}$ no overall trend was observed for the response of $\mathrm{NPP}_{\text {stem }}$ to changes in $\mathrm{NPP}_{\text {total }}$, but the site-specific variability observed in the data point towards a greater plasticity in stem allocation. Several studies have suggested that plants tend to maximize growth rates by partitioning carbon to differ-

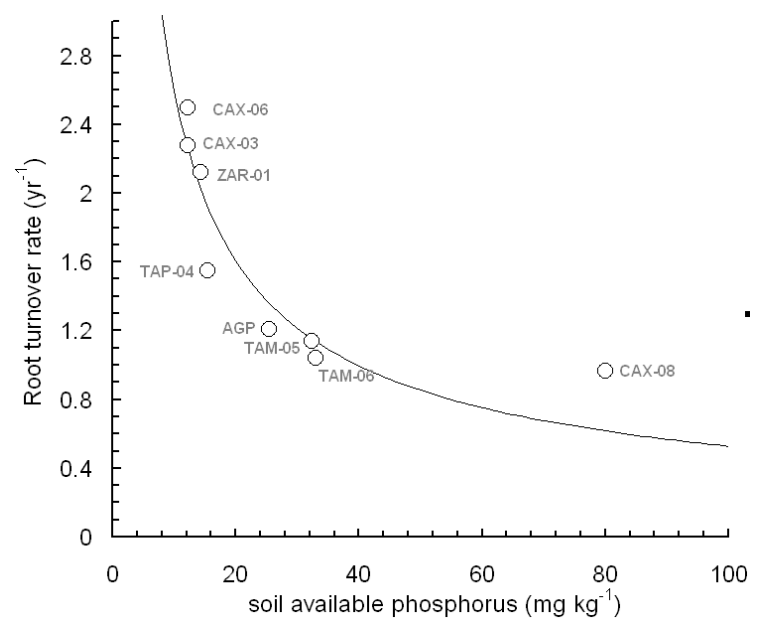

Fig. 9. The relationship between fine root turnover rate (fine root biomass/fine root production) and soil available phosphorus concentration. The regression line in black indicates a power fit (Fine root turnover=12.74 $( \pm 4.75) \times\left(\mathrm{P}_{\text {soil }}\right)^{-0.69( \pm 0.13)}, R^{2}=0.86, n=8$, $p<0.01)$.

ent compartments to optimize competition for limiting resources (e.g. Cannell and Dewar, 1994; Friend et al., 1994; McConnaughay and Coleman, 1999; Litton et al., 2007).

\subsection{Is the partitioning between $\mathbf{N P P}_{\mathrm{AG}}$ and $\mathrm{NPP}_{\mathrm{BG}}$ in- variant with changes in $\mathbf{N P P}_{\text {total }}$ ?}

The fractional partitioning of $\mathrm{NPP}_{\text {total }}$ into its above- and below-ground components seems to be invariant for the dataset analysed. However, the Tapajós site has a much greater allocation above-ground than expected, indicating that disturbance changes allocation pattern in Amazonian forests (Malhi et al., 2009). It is interesting that the partitioning to $\mathrm{NPP}_{\mathrm{BG}}\left(\mathrm{NPP}_{\mathrm{BG}} / \mathrm{NPP}_{\text {total }}\right)$ significantly decreases 
with the increase of $\mathrm{NPP}_{\text {stem }}$, but does not correlate either with $\mathrm{NPP}_{\mathrm{AG}}$ or $\mathrm{NPP}_{\text {canopy. Therefore, we expect that sites }}$ with higher stem growth have proportionally lower root production. This pattern appears to be driven by sites that have been either disturbed (TAP-04) (Pyle et al., 2008; Malhi et al., 2009) or are very dynamic with high growth and mortality rates (AGP and TAM-06) (Quesada et al., 2009a). The high dynamism of AGP may be related to the undulating topography at these sites. In both cases, these forests are likely to contain few senescent individuals and many juvenile and maturing trees competing strongly for light, favouring allocation of carbon to gaining an improved position in the stand.

\subsection{Is the partitioning between $\mathbf{N P P}_{\text {stem }}$ and $\mathbf{N P P}_{\text {canopy }}$ constant?}

Using our data alone we did not find a significant relationship between $\mathrm{NPP}_{\text {stem }}$ and $\mathrm{NPP}_{\text {canopy }}$, but this is mainly due to the high stem and low litterfall production in the Colombian site (AGP). One possible explanation is that this is the wettest site (Table 1), and consequently may have greater decomposition rates than the drier sites and more herbivore activity, leading to underestimation of litterfall. Without considering this site our regression slope was similar to the one found by Malhi et al. (2004). Furthermore, the constant partitioning was retained when we evaluated the two datasets combined. Thus, apart from the Colombian site, the remaining plots are consistent with Malhi's relationship.

Overall it seems that the ratio between $\mathrm{NPP}_{\text {stem }}$ and $\mathrm{NPP}_{\text {canopy }}$ tends to be fairly constant across Amazonian forests, but there may be some variation at regional and local scale due to variation in species composition, allocation patterns, disturbance history, climatic regimes and soil properties.

\subsection{How does NPP vary with soil and leaf nutrient sta- tus?}

$\mathrm{NPP}_{\text {total }}$ increases with the availability of soil phosphorus, but does not respond clearly to soil nitrogen. This result supports the hypothesis that soil phosphorus instead of soil nitrogen is the main limiting nutrient of tropical forest productivity (Vitousek, 1982, 1984, 2004; Cuevas and Medina, 1986; Vitousek and Sanford, 1986; Silver, 1994; Reich et al., 1995; MacGrath et al., 2001; Paoli and Curran, 2007; Quesada et al., 2009a).

Another interesting finding is that below-ground production increases with available soil phosphorus. Despite the lack of trend observed for $\mathrm{NPP}_{\mathrm{AG}}$ with soil fertility, we found a significant increase of $\mathrm{NPP}_{\text {canopy }}$, but no trend in $\mathrm{NPP}_{\text {stem }}$ with soil phosphorus. These results are similar to the conclusions from the work of Nadelhoffer et al. (1985) studying temperate forests. These authors proposed that litterfall and fine-root production increases with forest soil fertility, in their case quantified as soil nitrogen. Moreover, litterfall and fine-root production may be controlled by the same factors (Raich and Nadelhoffer, 1989). In eastern Amazonian secondary forests, Gehring et al. (1999) reported that increased soil phosphorus tended to disproportionately favour greater leaf production over wood production, decreasing the leaf to wood ratio of fertilized plots in relation to control plots. This is analogous to the response observed in this study.

Absolute below-ground production appears invariant with the increase of soil clay content (although proportional below-ground allocation does decline; see next section). This result is consistent with previous findings for Tapajós site, in which no significant differences were found between fine root production in clay and sandy soils (Silver et al., 2005).

\subsection{Is the partitioning between $\mathrm{NPP}_{\mathrm{AG}}$ and $\mathrm{NPP}_{\mathrm{BG}}$ in- variant with changes in soil and leaf properties?}

Despite the increase of $\mathrm{NPP}_{\text {total }}$ and $\mathrm{NPP}_{\text {fineroot }}$ with soil phosphorus, we found that the proportional amount of $\mathrm{NPP}_{\text {total }}$ allocated above- and below-ground $\left(\mathrm{NPP}_{\mathrm{AG}} / \mathrm{NPP}_{\text {total }}\right.$ and $\mathrm{NPP}_{\mathrm{BG}} / \mathrm{NPP}_{\text {total }}$, respectively) tends to be invariant with soil and leaf nutrient status. This finding again is consistent with the work of Nadelhoffer et al. (1985) in temperate forests, where the ratio of above- to below-ground production did not increase along the nitrogen fertility gradient. This result goes against the source-sink theory (Bloom et al., 1985) where trees should allocate more energy to roots on infertile sites, as this investment in nutrient acquisition should yield increased growth and/or reproduction in a nutrient-limited site. Higher fine root biomass in infertile soils has been reported for the tropics (e.g. Vitousek and Sanford, 1986; Priess et al., 1999; Espeleta and Clark, 2007). However, our results suggest that this pattern is not driven by a greater fractional allocation to root production.

Therefore, we suggest that the observed difference in fine root biomass between high and low fertility soils is a consequence of root turnover rates, which may be higher in higher fertility soils and lower in low fertility soils (Nadelhoffer et al., 1985). This trend seems to be analogous to the observed turnover rates of the above-ground coarse wood productivity across Amazonian plots, where higher productivity sites have also higher turnover rates (Malhi et al., 2004). Our results on fine root turnover rates clearly showed the decline of fine root turnover following the decrease in soil available phosphorus, soil $\mathrm{N}$ and CEC, which reinforce this idea. This trend is likely to reflect a higher nutritional quality of fine roots in more fertile soils consequently inducing elevated decomposition rates (Silver and Miya, 2001). For instance, we observed a direct correlation between $\mathrm{P}_{\text {soil }}$ and $\mathrm{P}_{\text {leaf }}$ which indicates the connection between soil and plant nutrient status. On the other hand, soil $\mathrm{Al}$ toxicity may restrain root decomposition (Preiss et al., 1999) increasing turnover rates. However, we did not find evidences about the effect of soil $\mathrm{Al}$ content on root turnover in this study. 
The lack of correlation between below-ground allocation and soil phosphorus may be due to the possible underestimation of the above-ground productivity as discussed previously, which would potentially decrease the fractional belowground allocation in more fertile sites. Hence, this result must be interpreted with caution.

According to our results, soil texture, represented here by the proportion of clay in the soil, appears to be more important than soil fertility in determining the proportion of NPP allocated below-ground. Sites with higher clay content tend to allocate a lower proportion of their NPP to belowground. Carvalheiro and Nepstad (1996), studying an eastern Amazonian forest showed that fine-roots may proliferate in soils with low resistance to root penetration, even though levels of available nutrients in the soil are similar to, or lower than, levels in the adjacent soil offering higher resistance. This suggests that sandy soils may favour allocation to below-ground due in part to greater penetrability than clayrich soils. Moreover, poorer water holding capacity of sandy soils, leading to lower water content in these Amazonian soil types (Williams et al., 2002; Luizão et al., 2004), may induce the increase of root productivity to maintain soil water access during dry periods. Metcalfe et al. (2008), demonstrated a significant increase of fine root surface area in an experimental drought plot in Caxiuanã. However, other soil physical attributes could be expected to affect root production and allocation to below-ground. For instance, the waterlogged nature of the plinthosol is likely to inhibit root production and below-ground allocation in plots AGP-01 and AGP-02.

\section{Conclusions}

Our main results suggest that along a gradient of soil available phosphorus as an indicator of soil fertility (from low fertility to high fertility) in ten lowland Amazonian terra firme tropical forest sites:

1. total NPP increases, and tends to involve an increase in both above- and below-ground NPP;

2. fine litterfall and fine root production increases, while there is no overall trend in stem production, but with substantial site-to-site variability;

3. proportional allocation to below-ground $\left(\mathrm{NPP}_{\mathrm{BG}} /\right.$ $\left.\mathrm{NPP}_{\text {total }}\right)$ is fairly invariant.

In addition to the effect of soil fertility we also observed that:

1. allocation of $\mathrm{NPP}_{\text {total }}$ to below-ground increases with the decrease of soil clay content;

2. disturbed and highly dynamic forests appear to prioritize above-ground allocation, with increased $\mathrm{NPP}_{\text {stem }}$ and reduced NPP proportionally allocated to belowground;
3. $\mathrm{NPP}_{\text {stem }}$ seems to be a weak predictor of $\mathrm{NPP}_{\text {total }}$, while for undisturbed forests $\mathrm{NPP}_{\text {canopy }}$ appears to be a strong predictor of $\mathrm{NPP}_{\text {total }}$.

This study provides for the first time a spatially extensive assessment of above- and below-ground net primary production in Amazonian forests. However, it is important to note that, despite covering a range of forest types on contrasting soils, our results are based on a sample size of ten sites, and there is the potential for misinterpretation due to some peculiar sites and methodological issues. The conclusions drawn from this investigation will benefit from further testing using more sites not only in Amazonia itself, but also across the tropics. Furthermore, it would be very promising to examine these patterns in disturbed forests. Due to the ongoing deforestation and logging activities, leading to expanding cover of disturbed forests across the tropics, and their different allocation pattern, these ecosystems may have a significant role on regional patterns of production and carbon cycling.

Finally, an obvious question that emerges from this study is: which process is driving the NPP responses across the fertility gradient, an increase in photosynthetic rates, a decrease in autotrophic respiration rates, or both? Data on autotrophic respiration rates are being collected at a number of sites and the quantification of GPP and CUE for these sites is now a specific focus of our research in progress.

Acknowledgements. This work was funded by a UK Natural Environment Research Council (NERC) grant (NE/A/S/2003/00608/2) and partially funded through the European Union-funded PANAMAZONIA programme. The collection of stem productivity data at TAM, AGP and ZAR was supported by the NERC (NE/D01025X/1). We would like to thank William Farfan and Karina Garcia for helping with installation of the intensive experiments at Tambopata, and Gabriela Lopez-Gonzalez for developing the stem productivity database, with funding from the Gordon and Betty Moore Foundation (grant to RAINFOR) and the School of Geography, University of Leeds. We also thank the Resident Naturalists at Explorer's Inn in Tambopata and field assistants at Caxiuanã field station for their valuable help with the processing of root samples. Co-authors are listed in two groups according to their contribution to this work: the first ten co-authors have contributed significantly for the data analysis and writing of this manuscript; the second group is listed alphabetically and are mostly field and lab participants that contributed with essential and substantial effort on data acquisition and sample processing.

Edited by: J. Lloyd

\section{References}

Anderson, L. O., Malhi, Y., Ladle, R. J., Aragão, L. E. O. C., Shimabukuro, Y., Phillips, O. L., Baker, T., Costa, A. C. L., Espejo, J. S., Higuchi, N., Laurance, W. F., López-González, G., Monteagudo, A., Núñez-Vargas, P., Peacock, J., Quesada, C. A., and Almeida, S.: Influence of landscape heterogeneity on spatial patterns of wood productivity, wood specific density and above 
ground biomass in Amazonia, Biogeosciences, 6, 1883-1902, 2009 ,

http://www.biogeosciences.net/6/1883/2009/.

Araújo, A. C., Nobre, A. D., Kruijt, B., Elbers, J. A., Dallarosa, R., Stefani, P., von Randow, C., Manzi, A. O., Culf, A. D., Gash, J. H. C., Valentini, R., and Kabat, P.: Comparative measurements of carbon dioxide fluxes from two nearby towers in a central Amazonian rainforest: The Manaus LBA site, J. Geophys. Res.Atmos., 107(D20), 8090, doi:10.1029/2001JD000676, 2002.

Baker, T. R., Phillips, O. L., Malhi, Y., Almeida, S., Arroyo, L., Di Fiore, A., Erwin, T., Killeen, T. J., Laurance, S. G., Laurance, W. G., Lewis, S., Lloyd, J., Monteagudo, A., Neill, D. A., Patino, S., Pitman, N. C. A., Silva, J. M. N., and Martines, R. V.: Variation in wood density determines spatial patterns in Amazonian forest biomass, Global Change Biol., 10, 545-562, 2004.

Bartholomé, E. and Belward, A. S.: GLC2000: a new approach to global land cover mapping from Earth observation data, Int. J. Remote Sens., 26, 9, doi:10.1080/01431160412331291297, 2005.

Bloom, A. J., Chapin, F. S. III, and Mooney, H. A.: Resource limitation in plants-an economic analogy, Ann. Rev. Ecol. Syst., 16, 363-392, 1985.

Cannell M. G. R. and Dewar, R. C.: Carbon allocation in trees: a review of concepts for modelling, Adv. Ecol. Res., 25, 59-104, 1994.

Carvalheiro, K. and Nepstad, D.: Deep soil heterogeneity and fine root distribution in forests and pastures of eastern Amazônia, Plant Soil, 182, 279-285, 1996.

Chambers, J. Q., dos Santos, J., Ribeiro, R. J., and Higuchi, N.: Tree damage, allometric relationships, and above-ground net primary production in central Amazon forest, Forest Ecol. Manag., 152, 73-84, 2001.

Chave, J., Navarrete, D., Almeida, S., Álvarez, E., Aragão, L. E. O. C., Bonal, D., Châtelet, P., Silva Espejo, J., Goret, J.-Y., von Hildebrand, P., Jiménez, E., Patiño, S., Peñuela, M. C., Phillips, O. L., Stevenson, P., and Malhi, Y.: Regional and temporal patterns of litterfall in tropical South America, Biogeosciences Discuss., 6, 7565-7597, 2009,

http://www.biogeosciences-discuss.net/6/7565/2009/.

Clark, D. A., Brown, S., Kicklighter, D. W., Chambers, J. Q., Thomlinson, J. R., Ni, J., and Holland, E. A.: Net primary production in tropical forests: An evaluation and synthesis of existing field data, Ecol. Appl., 11, 371-384, 2001a.

Clark, D. A., Brown, S., Kicklighter, D. W., Chambers, J. Q., Thomlinson, J. R., and Ni, J.: Measuring net primary production in forests: Concepts and field methods, Ecol. Appl., 11, 356-370, 2001b.

Cuevas, E. and Medina, E.: Nutrient dynamics within Amazonian forest ecosystems, Oecologia, 68, 466-472, 1986.

Del Grosso, S., Parton, W., Stohlgren, T., Zheng, D., Bachelet, D., Prince, S., Hibbard, K., and Olson, R.: Global potential net primary production predicted from vegetation class, precipitation, and temperature, Ecology, 89(8), 2117-2126, 2008.

Espeleta, J. F. and Clark, D. A.: Multi-scale variation in fine-root biomass in a tropical rain forest : A seven-year study, Ecological monographs, 77(3), 377-404, 2007.

Field, C. B., Behrenfeld, M. J., Randerson, J. T., and Falkowski, P.: Primary Production of the Biosphere: Integrating Terrestrial and Oceanic Components, Science, 281, 5374, doi:10.1126/science.281.5374.237, 1998.

Friend, A. L., Coleman, M. D., and Isebrands, J. G.: Carbon allocation to root and shoot systems of woody plants, in: Biology of Adventitious Root Formation, edited by: Davis, T. D. and Haissig, B. E., pp. 245-273, Plenum Press, New York, 1994.

Fyllas, N. M., Patiño, S., Baker, T. R., Bielefeld Nardoto, G., Martinelli, L. A., Quesada, C. A., Paiva, R., Schwarz, M., Horna, V., Mercado, L. M., Santos, A., Arroyo, L., Jiménez, E. M., Luizão, F. J., Neill, D. A., Silva, N., Prieto, A., Rudas, A., Silviera, M., Vieira, I. C. G., Lopez-Gonzalez, G., Malhi, Y., Phillips, O. L., and Lloyd, J.: Basin-wide variations in foliar properties of Amazonian forest: phylogeny, soils and climate, Biogeosciences Discuss., 6, 3707-3769, 2009,

http://www.biogeosciences-discuss.net/6/3707/2009/.

Gee, G. W. and Bauder, J. W.: Particle-size analysis, in: Methods in Soil Analysis. Part 1, Physical and Mineralogical Methods, American Society of Agronomy and Soil Science Society of America, Madison, Wisconsin, USA, 383-409, 1996.

Gehring, C., Denich, M., Kanashiro, M., and Vlek, P. L. G.: Response of secondary vegetation in Eastern Amazonia to relaxed nutrient availability constraints, Biogeochemistry-US, 45(3), 223-241, 1999.

Grace, J.: Understanding and managing the global carbon cycle, J. Ecol., 92(2), 189-202, 2004.

Hendricks, J. J., Hendrick, R. L., Wilson, C. A., Mitchell, R. J., Pecot, S. D., and Guo, D.: Assessing the patterns and controls of fine root dynamics: and empirical test and methodological review, J. Ecol., 94, 40-57, 2006.

Hutyra, L. R., Munger, J. W., Gottlieb, E. W., Daube, B. C., Camargo, P. B., and Wofsy, S. C.: Seasonal controls on the exchange of carbon and water in an Amazonian rainforest, J. Geophys. Res., 112, G03008, doi:10.1029/2006JG000365, 2007.

Jiménez, E. M., Moreno, F. H., Lloyd, J., Peñuela, M. C., and Pati no, S.: Fine root dynamics for forests on contrasting soils in the colombian Amazon, Biogeosciences Discuss., 6, 3415-3453, 2009 ,

http://www.biogeosciences-discuss.net/6/3415/2009/.

Kämpf, N., Woods. W. I., Sombroek, W., Kern, D. C., and Cunha, T. J. F.: Classification of Amazonian Dark Earths and other ancient anthropic soils Amazonian Dark Earths: Origin, Properties, Management, Kluwer Academic Publishers, Dordrecht, Netherlands, edited by: Lehmann, J., Kern, D. C., Glaser, B., and Woods, W. I., 77-104, 2003.

Keeling, H. C. and Phillips, O. L.: The global relationship between forest productivity and biomass, Global Ecol. Biogeogr., 16(5) 618-631, 2007.

Lehmann, J., Kern, D. C., Glaser, B., and Woods, W. I.: Amazonian Dark Earths: Origin, Properties, Management, Kluwer Academic Publishers, Dordrecht, Netherlands, 2003.

Litton, C. M., Raich, J. W., and Ryan, M. G.: Carbon allocation in forest ecosystems, Global Change Biol., 13, 2089-2109, 2007.

Lloyd, J., Patiño, S., Paiva, R. Q., Nardoto, G. B., Quesada, C. A., Santos, A. J. B., Baker, T. R., Brand, W. A., Hilke, I., Gielmann, H., Raessler, M., Luizão, F. J., Martinelli, L. A., and Mercado, L. M.: Variations in leaf physiological properties within Amazon forest canopies, Biogeosciences Discuss., 6, 4639-4692, 2009, http://www.biogeosciences-discuss.net/6/4639/2009/.

Luizão, R. C. C., Luizão, F. J., Paiva, R. Q., Monteiro, T. F., Sousa, L. S., and Kruijt, B.: Variation of carbon and nitrogen cycling 
processes along a topographic gradient in a central Amazonian forest, Global Change Biol., 10, 592-600, 2004.

Luyssaert, S., Inglima, I., Jung, M., Richardson, A. D., Reichstein, M., et al.: $\mathrm{CO} 2$ balance of boreal, temperate, and tropical forests derived from a global database, Global Change Biol., 13, 25092537, 2007.

Malhi, Y. and Grace, J.: Tropical forests and atmospheric carbon dioxide, Trends Ecol. Evol., 15, 332-337, 2000.

Malhi, Y., Aragão, L. E. O. C., Metcalfe, D. B., Paiva, R., Quesada, C. A., Almeida, S., Anderson, L., Brando, P., Chambers, J. Q., Costa, A. C. L., Hutyra, L., Oliveira, P., Patiño, S., Pyle, E. H., Robertson, A. L., and Teixeira, L. M.: Comprehensive assessment of carbon productivity, allocation and storage in three Amazonian forests, Global Change Biol., 15(5), 1255-1274, doi:10.1111/j.1365-2486.2008.01780.x, 2009.

Malhi, Y., Baker, T., Phillips, O. L., Almeida, S., Alvares, E., Arroyo, L., Chave, J., Czimczik, C., Di Fiore, A., Higuchi, N., Killeen, T., Laurance, S. G., Laurance, W. F., Lewis, S., Montoya, L. M. M., Monteagudo, A., Neill, D., Nunes Vargas, P., Panfil, S. N., Patiño, S., Pitman, N., Quesada, C. A., Salomão, R., Silva, N., Lezama, A. T., Vasquez Martinez, R., Terborgh, J., Vinceti, B., and Lloyd, J.: The above-ground coarse wood productivity of 104 neotropical forest plot, Global Change Biol., 10, 1-29, 2004.

Malhi, Y., Phillips, O. L., Lloyd, J., Baker, T., Wright, J., Almeida, S., Arroyo, L., Frederiksen, T., Grace, J., Higuchi, N., Killeen, T., Laurance, W. F., Leano, C., Lewis, S., Meir, P., Monteagudo, A., Neill, D., Nunes Vargas, P., Panfil, S. N., Patino, S., Pitman, N., Quesada, C. A., Rudas-L, A., Salomão, R., Saleska, S., Silva, N., Silveira, M., Sombroek, W. G., Valencia, R., VasquezMartinez, R., Vieira, I. C. G., and Vinceti, B.: An international network to monitor the structure, composition and dynamics of Amazonian forests (RAINFOR), J. Veg. Sci., 13, 439-450, 2002.

McConnaughay, K. D. M. and Coleman, J. S.: Biomass allocation in plants: ontogeny or optimality? A test along a three resource gradients, Ecology, 80, 2581-2593, 1999.

McGrath, D. A., Smith, C. K., Gholz, H. L., and Oliveira, F. A.: Effects of land-use change on soil nutrient dynamics in Amazonia, Ecosystems, 4, 625-645, 2001.

Metcalfe, D., Mier, P., and Williams, M.: The effects of water availability on root growth and morphology in an Amazon rainforest, Plant and Soil, 311, 189-199, 2008.

Metcalfe, D. B., Meir, P., Aragão, L. E. O. C., Malhi, Y., Costa, A. C. L., Braga, A., Gonçalves, P. H. L., Athaydes, J., Almeida, S., and Williams, M.: Factors controlling spatio-temporal variation in carbon dioxide efflux from surface litter, roots, and soil organic matter at four rain forest sites in the eastern Amazon, J. Geophys. Res.-Biog, 112, G04001, doi:10.1029/2007JG000443, 2007a.

Metcalfe, D. B., Williams, M., Aragão, L. E. O. C., da Costa, A. C. L., de Almeida, S. S., Braga, A. P., Gonçalves, P. H. L., de Athaydes, S. J. J., Malhi, Y., and Meir, P.: A method for extracting plant roots from soil which facilitates rapid sample processing without compromising measurement accuracy, New Phytol., 174, 697-703, 2007b.

Nadelhoffer, K. J., Aber, J. D., and Mellilo, J. M.: Fine roots, net primary production, and soil nitrogen availability: A new hypothesis, Ecology, 66(4), 1377-1390, 1985.

Nelson, D. W. and Sommers, L. E.: Total carbon and total nitro- gen, in: Methods of Soil Analysis: Part 3 - Chemical Methods, SSSA Book Series No 5, SSSA and ASA, Madison, WI, edited by: Sparks, D. L., 961-1010, 1996.

Nepstad, D. C., Moutinho, P., Dias, M. B., et al.: The effects of partial throughfall exclusion on canopy processes, aboveground production, and biogeochemistry of an Amazon forest, J. Geophys. Res.-Atmos., 107(D20), 8085, doi:10.1029/2001JD000360, 2002.

Paoli, G. D. and Curran, L. M.: Soil nutrients limit fine litter production and tree growth in mature lowland forest of southwestern Borneo, Ecosystems, 10, 503-518, 2007.

Pella, E.: Elemental organic analysis. Part 2. State of the art, American Laboratory, 22, 28-32, 1990.

Phillips, O. L., Aragão, L. E. O. C., Lewis, S. L., et al.: Drought sensitivity of the Amazon rainforest, Science, 323, 1344-1347, 2009.

Priess, J., Then, C., and Fölster, H.: Litter and fine-root production in three types of tropical premontane rainforest in SE Venezuela, Plant Ecology, 143, 171-187, 1999.

Pyle, E. H., Santoni, G. W., Nascimento, H. E. M., et al: Dynamics of carbon, biomass and structure in two Amazonian Forests, J. Geophys. Res-Biogeos, 113, G00B08, doi:10.1029/2007JG000592.

Quesada, C. A., Lloyd, J., Schwarz, M., Baker, T. R., Phillips, O. L., Patiño, S., Czimczik, C., Hodnett, M. G., Herrera, R., Arneth, A., Lloyd, G., Malhi, Y., Dezzeo, N., Luizão, F. J., Santos, A. J. B., Schmerler, J., Arroyo, L., Silveira, M., Priante Filho, N., Jimenez, E. M., Paiva, R., Vieira, I., Neill, D. A., Silva, N., Peñuela, M. C., Monteagudo, A., Vásquez, R., Prieto, A., Rudas, A., Almeida, S., Higuchi, N., Lezama, A. T., López-González, G., Peacock, J., Fyllas, N. M., Alvarez Dávila, E., Erwin, T., di Fiore, A., Chao, K. J., Honorio, E., Killeen, T., Peña Cruz, A., Pitman, N., Nñez Vargas, P., Salomão, R., Terborgh, J., and Ramrez, H.: Regional and large-scale patterns in Amazon forest structure and function are mediated by variations in soil physical and chemical properties, Biogeosciences Discuss., 6, 39934057, 2009a, http://www.biogeosciences-discuss.net/6/3993/2009/.

Quesada, C. A., Lloyd, J., Anderson, L. O., Fyllas, N. M., Schwarz, M., and Czimczik, C. I.: Soils of amazonia with particular reference to the rainfor sites, Biogeosciences Discuss., 6, 3851-3921, 2009b, http://www.biogeosciences-discuss.net/6/3851/2009/.

Quesada, C. A., Lloyd, J., Schwarz, M., Patiño, S., Baker, T. R., Czimczik, C., Fyllas, N. M., Martinelli, L., Nardoto, G. B., Schmerler, J., Santos, A. J. B., Hodnett, M. G., Herrera, R., Luizão, F. J., Arneth, A., Lloyd, G., Dezzeo, N., Hilke, I., Kuhlmann, I., Raessler, M., Brand, W. A., Geilmann, H., Moraes Filho, J. O., Carvalho, F. P., Araujo Filho, R. N., Chaves, J. E., Cruz Junior, O. F., Pimentel, T. P., and Paiva, R.: Chemical and physical properties of Amazon forest soils in relation to their genesis, Biogeosciences Discuss., 6, 3923-3992, 2009c, http://www.biogeosciences-discuss.net/6/3923/2009/.

Raich, J. W. and Nadelhoffer, K. J.: Belowground carbon allocation in forest ecosystems: Global trends, Ecology, 70(5), 1346-1354, 1989.

Reich, P. B., Ellsworth, D. S., and Uhl, C.: Leaf carbon and nutrient assimilation and conservation in species of different successional status in an oligotrophic Amazonian forest, Funct. Ecol., 9, 65- 
76, 1995.

Rice, A. H., Pyle, E. H., Saleska, S. R., Hutyra, L., Palace, M., Keller, M., Camargo, P. B., Portilho, K., Marques, D. F., and Wofsy, S. C.: Carbon balance and vegetation dynamics in an oldgrowth Amazonian forest, Ecol. Appl., 14, 55-71, 2004.

Ruivo, M. L. P. and Cunha, E. S.: Mineral and organic components in archaeological black earth and yellow latosol in Caxiuanã, Amazon, Brazil, in: Ecosystems and sustainable development, edited by: Tiezzi, E., Brebbia, C. A., and Uso, J. L., WIT, Southampton, 1113-1121, 2003.

Saleska, S. R., Miller, S. D., Matross, D. M., Goulden, M. L., Wofsy, S. C., da Rocha, H., de Camargo, P. B., Crill, P., Daube, B. C., de Freitas, H. C., Hutyra, L., Keller, M., Kirchhoff, V., Menton, M., Munger, J. W., Pyle, E. H., Rice, A. H., and Silva, H.: Carbon in Amazon forests: Unexpected seasonal fluxes and disturbance-induced losses, Science, 302, 1554-1557, 2003.

Sanantonio, D. and Grace, J. C.: Estimating fine-root production and turnover from biomass and decomposition data - a compartment flow model, Can. J. Forest Res., 17, 900-908, 1987.

Silver, W. L.: Is nutrient availability related to plant nutrient use in humid tropical forests?, Oecologia, 98, 336-343, 1994.
Silver, W. L., Neff, J., McGroddy, M., Veldkamp, E., Keller, M., and Cosme, R.: Effects of soil texture on belowground carbon and nutrient storage in a lowland Amazonian forest ecosystem, Ecosystems, 3, 193-209, 2000.

Silver, W. L. and Miya, R.: Global patterns in root decomposition: comparisons of climate and litter quality effects, Oecologia, 129, 407-419, 2001.

Silver, W. L., Thompson, A. W., McGroddy, M. E., Varner, R. K., Dias, J. D., Silva, H., Crill, P. M., and Keller, M.: Fine root dynamics and trace gas fluxes in two lowland tropical forest soils, Global Change Biol., 11, 290-306, 2005.

Vitousek, P. M. and Sanford, R. L.: Nutrient cycling in moist tropical forest, Annu. Rev. Ecol. Syst., 17, 137-167, 1986.

Vitousek, P. M.: Nutrient cycling and nutrient use efficiency, The American Naturalist, 119, 553-572, 1982.

Vitousek, P. M.: Litterfall, nutrient cycling, and nutrient limitation in tropical forests, Ecology, 65, 285-298, 1984.

Vitousek, P. M.: Nutrient Cycling and Limitation: Hawai'i as a Model System, Princeton University Press, 2004. 